4 norden

\title{
Guidelines for food safety control of artisan cheese-making
}

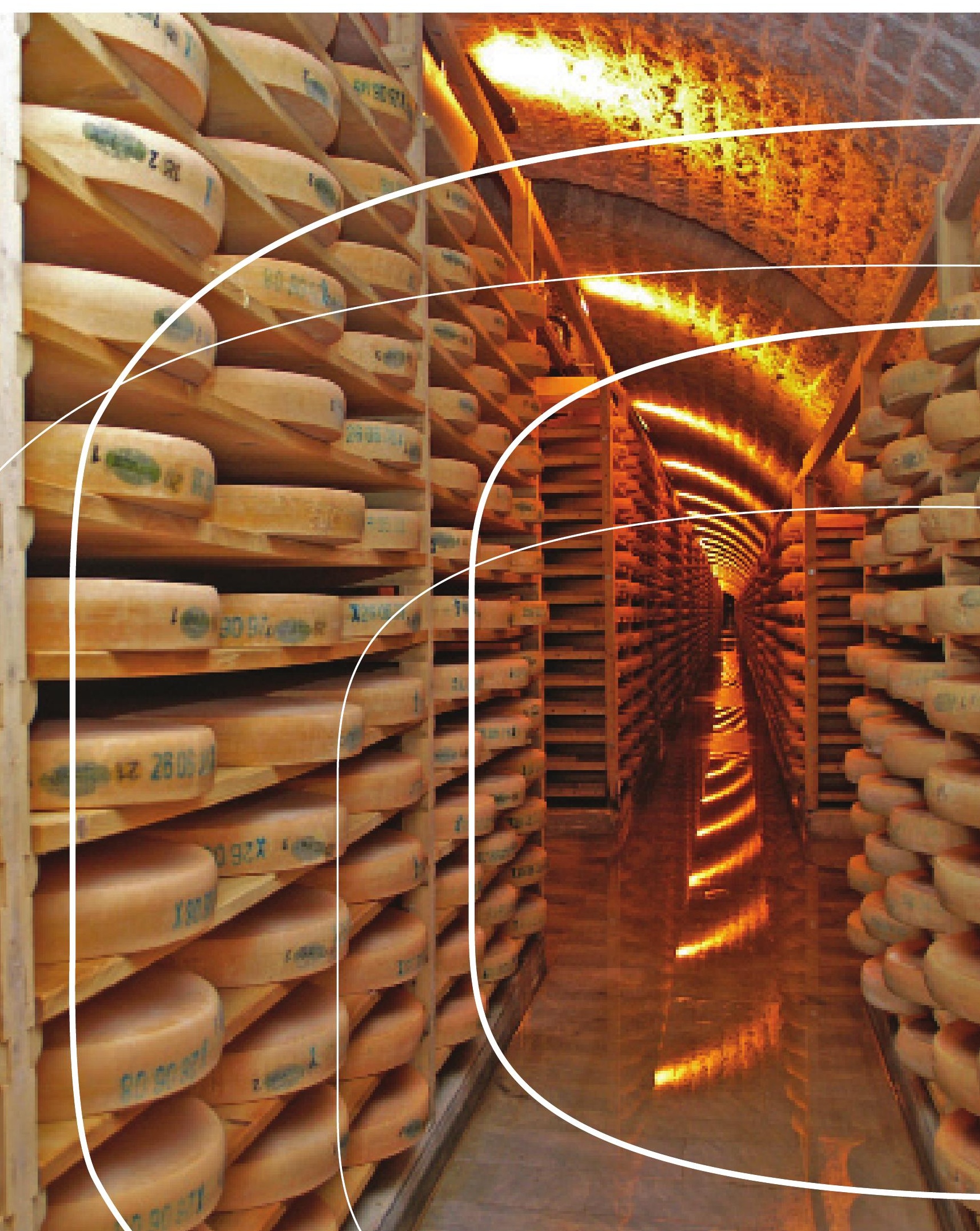


4 nordon 



\section{Guidelines for food safety control of artisan cheese-making}

Ida Olofsson

TemaNord 2010:596 


\section{Guidelines for food safety control of artisan cheese-making}

TemaNord 2010:596

(C) Nordic Council of Ministers, Copenhagen 2010

ISBN 978-92-893-2165-5

Cover photo: Image Select

Printed on environmentally friendly paper

This publication can be ordered on www.norden.org/order. Other Nordic publications are available at www.norden.org/publications

This publication has been published with financial support by the Nordic Council of Ministers. But the contents of this publication do not necessarily reflect the views, policies or recommendations of the Nordic Council of Ministers.

\section{Nordic Council of Ministers}

Ved Stranden 18

DK-1061 København K

Phone (+45) 33960200

Fax (+45) 33960202

\section{Nordic Counci}

Ved Stranden 18

DK-1061 København K

Phone (+45) 33960400

Fax (+45) 33111870

www.norden.org

\section{Nordic co-operation}

Nordic co-operation is one of the world's most extensive forms of regional collaboration, involving Denmark, Finland, Iceland, Norway, Sweden, and three autonomous areas: the Faroe Islands, Greenland, and Åland.

Nordic co-operation has firm traditions in politics, the economy, and culture. It plays an important role in European and international collaboration, and aims at creating a strong Nordic community in c strong Europe.

Nordic co-operation seeks to safeguard Nordic and regional interests and principles in the global community. Common Nordic values help the region solidify its position as one of the world's most innovative and competitive. 


\section{Table of Contents}

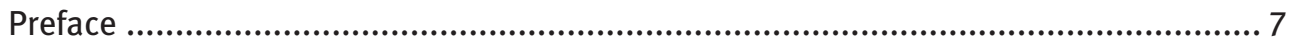

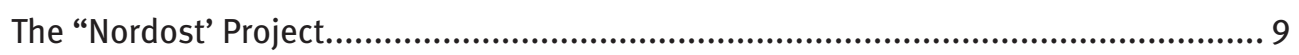

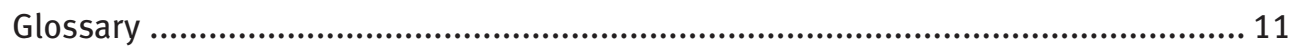

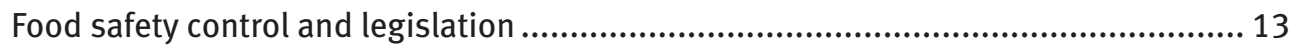

The difference between risk factors in the past and today........................................ 15

Adequate production procedures, good hygiene practice and HACCP........................ 17

What should a HACCP plan include? ...................................................................... 19

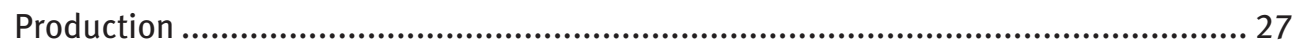

Documentation of cheese-making ........................................................................ 31

Critical control points and control points in cheese-making with pasteurised milk ............. 35

Critical control points and control points in cheese-making with unpasteurised milk......... 40

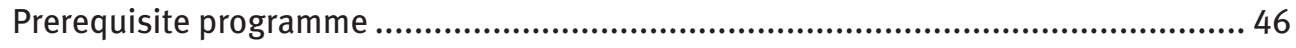

Cleaning wooden equipment............................................................................... 49

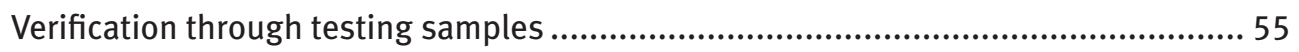

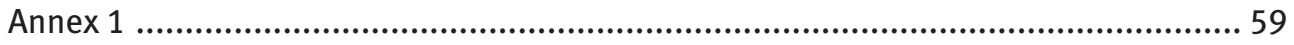

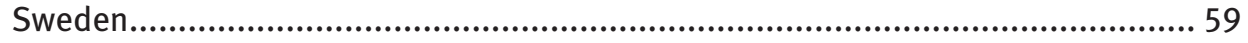

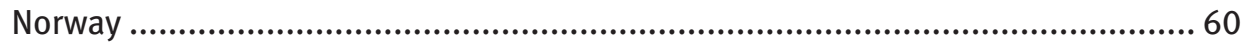

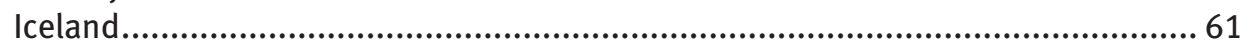

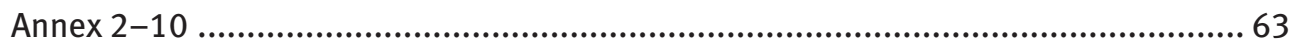





\section{Preface}

These guidelines ${ }^{1}$ have been formulated as part of the project "Nordic co-operation between representatives of the sector and food safety inspectors in order to simplify the food safety control of artisan cheese-making", also known as "Nordost" (Northern Cheese). The project is financed by the Nordic Council of Ministers and was initiated by the Nordic work group for "Food administration and user/consumer information" (the NMF group). The content of the guidelines and the appendices does not necessarily reflect the opinions of the Nordic Council of Ministers or the National Food Administration.

Artisan cheese-making takes place under greatly varying conditions, which can include everything from cheese-making in tiled dairies to production in primitive summerpasture villages. Nevertheless, irrespective of the environment in which it takes place, the cheese-making process is the same and the same demands apply, namely that the cheese shall be safe for consumers to eat.

The producer must ensure that the cheese does not represent a health hazard and that it is suitable for human consumption. It shall also be correctly labelled. When the cheese is sold directly to the consumer, correct information about the cheese must be provided. The objective is that the consumer should not suffer from eating the cheese and that the cheese should have the expected flavour and consistency. Each step of the cheese-making process should be included in the producer's system for own control and this quality control system should also function as a preventive measure that ensures that products do not represent a hazard to the health of the consumers. The producer must be able to validate the food safety of the cheeses that are produced in the specific way employed in his/her enterprise. Furthermore, the producer must regularly verify that the own control process and the validated work schedules are followed. This may be done using one of many different follow-up methods, for example following up that the schedules are followed (always work in the same way), the use of tests and analyses that show that own control takes place and gives satisfactory results (Do I do things in the correct manner and do I get satisfactory results?).

The job of food safety inspectors is to check that this is carried out as described above. The producer shall be able to show the food safety control authority that the company's system for quality control works satisfactorily. Both the inspector and the producer shall meet the requirements of the relevant food legislation in their safety routines (see Appendix 1). To help them in this task they can refer to the guidelines and recommendations that can be found on the websites of the National Food Administrations of the Nordic countries . ${ }^{2}$

The objective of these guidelines is to:

- both provide support to food safety inspectors in carrying out efficient food safety control by focusing on the relevant hazards associated with artisan cheese-making,

- and to disseminate the results of the sub-projects in "Nordost". Several of these sub-projects have studied relevant literature and tested equipment that enables simple, effective own control by producers.

2 www.livsmedelsverket.se, www.mattilsynet.no 
These guidelines cover important steps in the production of cheese from both pasteurised and unpasteurised milk in farm dairies or summer-pasture villages, but do not discuss the production of other milk products. The guidelines are also, to a certain extent, written for producers, as mentioned above, and include some suggestions for them (marked in the margin with Hint).

The guidelines should be followed in combination with the current legislation and recommendations in the respective countries (Sweden, Norway and Iceland) (see Appendix 1). Information can also be found in the Swedish Code of best Practice for cheesemaking (published by Eldrimner ${ }^{3}$ ) that can be accessed via the website of the Swedish National Food Administration ${ }^{4}$ and in the Norwegian version which will be published by Norsk Gardsost ${ }^{5}$.

This manual has been produced by Ida Olofsson, assisted by Susanne Sylvén from the Swedish National Food Administration. Valuable contributions have been made by Tina Dyrvold Carlsson, from the Municipality of Härjedalen, Lena Eriksson, from the Municipality of Älvdalen, Kerstin Jürss, from Jürss Dairy, Sven Lindgren, from Biofood AB, Ragnhild Nordbo, Norsk gardsost, Ylva Persson, from the Swedish Veterinary Institute, Folke Petré, from the City of Stockholm's Environmental Administration, Åsa Rosengren, from the Swedish National Food Administration, Lena Selberg, from the Municipality of Ånge, Birgitta Sundin, from Eldrimner, Agneta Svensson, from Arla Foods Falkenberg. 


\section{The "Nordost" Project}

The organisation of the project started in the autumn of 2007 at a meeting for Nordic countries in Uppsala, Sweden, on 24-25th October. The theme of the meeting was "Do we carry out food safety control in the best way?" Representatives of the sector and the relevant authorities in Sweden, Norway and Iceland participated and discussed how producers can carry out simple, effective own control and what support the project can provide to food safety inspectors so that they can focus on the relevant hazards associated with artisan cheese-making. The discussions resulted in a list of prioritised projects. From this list, the following sub-projects were carried out in 2008-2009. Reports from most of them are possible to order from the secretary of the NMF-group of the Nordic Council of Ministers, for the moment situated at the Swedish National Food Adminstration

Appendix 2 HACCP First Aid Kit, Niklas Ekman, Adaptsia AB, Sverige

Appendix 3 Summary of symposium "Safety Issues of Raw Milk Cheese" in Brussels, Dec. 2008, Ann-Charlotte Steneryd, Falkenbergs Environmental Health and Safety Administration

Appendix 4 To test or not to test - guidelines for microbiological testing in relation to artisan cheese-making. Åsa Rosengren and Mats Lindblad, the National Food Administration, Sweden.

Appendix 5 The cultivation and control of starter cultures in artisan cheese-making, Holmgeir Karlsson, Iceland

Appendix 6 Analysis equipment for farm dairies, Ida Olofsson, Rösta Educational Dairy, Sweden

Appendix 7 Methods for discovering subclinical mastitis in goats. Ylva Persson, SVA, Sweden (2 appendices)

Appendix 8 The occurrence and prevention of unwanted micro-organisms and impurities in small-scale dairying in Norway. 2008. Resource Centre, Sogn Agricultural and Horticultural Institute. Ragnhild Nordbo, Pascale Baudonnel, Norway

Appendix 9 The effects of biofilms in small-scale cheese-making, Sven Lindgren, Biofood AB, Sweden

Appendix 10 The use and management of different materials in connection with cheese-making at various summer-pasture villages, Lena Eriksson, Municipality of Älvdalen, Sweden (1 appendix) 



\section{Glossary}

\author{
Casein micelle \\ CCP \\ cfu \\ Cheese yield \\ Coagulation time \\ Delayed acidification \\ Draining
}

Gram negative bacteria

Gram positive bacteria

HACCP

Lag phase

Mastitis

Mesophilic culture
A suspension of particles of the protein casein

\section{Critical Control Point}

Colony-forming unit (a measure of the amount of microorganisms per unit)

The amount of cheese produced from a given quantity of milk

The time it takes for the milk to coagulate after the rennet has been added

A cheese-making problem which results in a visible hard core in the centre of the cheese

The step in cheese-making in which the whey is expelled from the curd

Bacteria that have a negative reaction (turn red) in a Gram stain test ${ }^{6}$. Many pathogenic bacteria are included in this group, such as the Escherchia, Klebsiella, Salmonella and Yersina species.

Bacteria that have a positive reaction (turn violet/blue) in a Gram stain test. Many beneficial bacteria are included in this group, such as the Lactococcus, Leuconostoc, Lactobacillus, Brevibacterium and Propionibacterium species. This group also includes pathogenic bacteria such as rhe Staphylococcus, Streptococcus and Listeria species.

\section{Hazard Analysis and Critical Control Points}

The phase when bacteria adapt to a new environment and grow, but do not reproduce themselves

Inflammation of the udder

Lactic acid starter culture that develops best at a temperature of $20-40^{\circ} C^{7}$

6 Livsmedelsteknologi 1 Konserveringsmetoder, P.E Andersen, J Risum, Studentlitteratur 1991

7 Mejeriboken från gräs till konsument, Erhversskolernes Forlag 2003, ISBN:87-7881-441-3 
Milk serum

Pathogen

Persistent

Pre-maturation

Psychrophilic bacteria

Pychotrophic bacteria

Sub-clinical mastitis

Synergic effect

Thermophilic culture

Thörner degrees

Validating

Verification is the liquid portion of milk, i.e. milk without any fat or protein

something that causes disease

difficult to obliterate

The step in cheese-making when the lactic acid bacteria from the starter culture multiply in the milk before the rennet is added

bacteria that thrive in cold temperatures, such as $0-28^{\circ} \mathrm{C}^{8}$

bacteria that can survive in a cold environment: they can reproduce themselves at temperatures under $7^{\circ} \mathrm{C}$. This group includes both mesophilic and psychrophilic bacteria?

inflammation of the udder without visible symptoms

the components strengthen each other's effects

A starter culture that grows best at a temperature of 45 $60^{\circ} \mathrm{C}^{10}$. This type of starter is often used in cheese making at a temperature of $35^{\circ} \mathrm{C}$, although it thrives better in a warmer environment.

A measurement for expressing titratable acidity

Expressing that "If I do this, food safety will be ensured". Evidence is produced that ensures that if a producer follows all the given steps and measures it will result in a safe cheese.

The producer verifies that "I do things in the correct way and I get good results". The producer checks regularly that the validated working routines and own control procedures are followed and give good results. 


\section{Food safety control and legislation}

As a producer of foodstuffs you are obliged to follow the relevant legislation. The purpose of food hygiene legislation is to protect the consumer from illnesses caused by food. Ultimately the legislation also protects producers, as there is no future for entrepreneurs that produce unsafe food. 



\section{The difference between risk factors in the past and today}

Does cheese-making today differ from in the past? Have the risks changed? Are bacteria more dangerous today than they were previously? Have the risks increased? We do not know the answer to these questions and may never know. Modern cheese-makers cater to a larger market spread over a wider area than their colleagues did a hundred years ago. This means that illness caused by eating cheese can spread rapidly over a widespread area and affect more consumers, and in some cases it may be hard to trace the infection to a specific product. Another problem is that there is now more contact between livestock on different farms, which means that bacteria hazardous to health can spread rapidly. The ability to investigate and discover food-borne illnesses has increased and "new" hazardous organisms are quite frequently discovered, such as verotoxin-producing E.coli bacteria (VTEC/EHEC). Possibly, these bacteria existed previously, but could not be detected by the methods used earlier. Much indicates, however, that they are actually "new" organisms that have developed the ability to cause serious and even fatal illnesses. 



\section{Adequate production procedures, good hygiene practice and HACCP ${ }^{11}$}

In general, it can be said that many hazards may be eliminated by employing adequate procedures in the prerequisite programme for production, i.e. adopting what is known as good manufacturing practice and good hygiene practice. Good Manufacturing Practice (GMP) is often said to be essential for a manufacturing business. If one compares the quality system with a house, GMP represents the foundation (see the cover of this manual). In the case of food companies, good hygiene practice (GHP) is also a necessary part of the prerequisite programme. It represents the walls of the house. Finally, as the roof, we have the company's own monitoring process, in which they examine the specific hazards related to their own processes and products (make hazard analyses, identify critical control points, monitor and take measures to deal with the results of these). This system is known as HACCP (Hazard Analysis and Critical Control Points). HACCP is employed continuously. It is employed before the production starts, each day in the production process and is documented by updating the records when changes in the production process occur. It is also important to follow developments in the relevant field in order to be aware of new hazards and be able to avoid the risks they represent. In-service training and exchanging knowledge with colleagues are good ways of keeping up-to-date. It is important that the HACCP plan is well-established with the food business operator and that it is relevant to the specific establishment and product group.

\footnotetext{
${ }^{11}$ In accordance with EC Regulation no. 852/2004 every production place shall have a quality control system that aims to prevent possible hazards in order that the foodstuffs produced shall not be pathogenic or unsuitable for human consumption.
} 



\section{What should a HACCP plan include?}

This is well-documented, for instance in the "Codex document on general principles for food hygiene including HACCP"12 or in EU Regulation 852/2004: Article $5^{13}$. The content of the guidelines and the appendices do not necessarily reflect the opinions of the Nordic Council of Ministers or the National Food Administration. Special courses in this subject are also available. The producer /manufacturer is always responsible for formulating a HACCP plan, or employing an existing HACCP plan that has been formulated for a specific product or process, if the control authority and the cheese producer judge that the plan is relevant to the business in question. See also the sub-project HACCP First Aid $\mathrm{Kit}^{14}$ (Appendix 2) and the information in the chapter on HACCP in the guidelines for the food sector "Safe Food in Shop" (Svensk Dagligvaruhandel) and "Hygienic Production of Milk Products" (Swedish Dairy Association), which can be accessed via the website of the National Food Administration (www.slv.se). If the milk used for cheese-making is bought from a farm, it is recommended that the farmer also takes part in formulating the HACCP plan (see Appendix 3 ) $^{15}$. In a survey conducted by Lena Eriksson from the Municipality of Älvdalen, on outbreaks of disease in which milk products were thought to be the source of infection, the results of her interviews stressed the importance of each company carrying out rigorous own control procedures. Not only should they have adequate own control of their dairy work and cheese-making, but also adequate procedures for own control of the quality of animal feed, the health of livestock and milk quality in the production of dairy produce. The quality of the milk is of particular importance in the production of unpasteurised dairy products.

\section{Description of the product/process}

A description of the hazard analysis etc. is given under this heading in the HACCP plan. It may include several hazard analyses, each one covering different steps in the production chain for the product/process in question. It is important to describe the points at which the analysis starts and finishes, for example whether the milk comes from another producer or if it is produced on the farm, whether the products are sold directly to the consumer and/or how the distribution of produce to wholesalers takes place. The idea behind the product description is that it provides an overview of the factors associated with the product/process that can affect the HACCP plan. For instance, this may include the raw materials used (milk, cultures, rennet, salt, spices, packaging etc.), if the milk is pasteurised or has been treated in any other way, the consumer group for which the product is suitable etc. (See hint under the heading Fair practices).

\footnotetext{
12 http://www.codexalimentarius.net/download/standards/23/cxp_001e.pdf

${ }^{13}$ http://eur-lex.europa.eu/LexUriServ/LexUriServ.do?uri=0J:L:2004:226:0003:0021:SV:PDF

14 Bilaga 2: HACCP First Aid kit, Niklas Ekman, adaptsia AB, Sverige

15 Bilaga 3: Sammanfattning av symposiet "Safety Issues of Raw Milk Cheese” i Bryssel 2008-12-11-12,

AnnCharlotte Steneryd, Falkenberg Miljö- och Hälsoskydd
} 


\section{Flow diagram}

A flow diagram provides a good overview of all the steps in the production process. The temperature, time period and critical control points identified can all be specified in the chart. Figure 1 shows an example of a flow diagram for the milking process.

Feed of acceptable quality, good animal husbandry, clean and healthy livestock
1. Wiping and possibly washing of the udder

2. Foremilking

3. Hand or machine milking

4. Cooling of milk to $4^{\circ} \mathrm{C}$ within 3 hours or milk to be used within 2 hours of milking

5. Milk transported to dairy

Figure 1. Example of a flow diagram for milking

If the milk is from the dairy's own herd, the work with the livestock must be included in the flow chart. This includes work such as feed management, feeding of livestock, mucking out and milking. It is not compulsory to have a flow chart for milk production or milking. The producer must, however, be aware of the hazards that can affect cheese-making and its final product, for example, that milking-animals must be healthy, the milk must be free from antibiotics, that the withholding period after treatment with medicines is respected, that neither the animal nor its udder are dirty or contaminated and that the feed management and animal husbandry are of an acceptable standard. If farmers are aware of these factors regarding the health of their livestock, they should also be able to produce high quality milk by milking the right animals. 


Raw material and biproduct $\quad$ Step in process
Good quality milk $\quad \Rightarrow \quad \begin{aligned} & \text { 1. Reception of milk and } \\ & \text { storage }\end{aligned}$

Antibiotic check

A. Milk to be pasteun CCP

ised, keep at $6.0^{\circ} \mathrm{C}$ for

$48 \mathrm{~h}, \max 72 \mathrm{~h}$ from

start of milking

B. Milk to be used

unpasteurised, keep at

$6.0^{\circ} \mathrm{C}$ for $12 \mathrm{~h}, \max 24 \mathrm{~h}$

\section{Pasteurisation (voluntary)}

3. Cooling of pasteurised milk or warming of cooled unpasteurised milk

$\begin{array}{lll}\text { Starter culture }(0,5-2 \%) & \Rightarrow 4 \text {. Add starter culture } \\ \text { Mould culture } & \Rightarrow 5 \text {. Add mould spores }\end{array}$

(according to the producer's recommendations)

Rennet

(approx $25 \mathrm{ml}$ dairy rennet/100 litre milk))

$\Rightarrow$

6. Pre-maturation

\section{Löpetillsats/koagulering}

8. Cutting the card and scalding

9. Moulding/acidification $63^{\circ} \mathrm{C}$ for $30 \mathrm{~min}$

To $30-32^{\circ} \mathrm{C}$ in $1-2 \mathrm{~h}$ $30-32^{\circ} \mathrm{C}$

$30-32^{\circ} \mathrm{C}$

$30-32^{\circ} \mathrm{C} 10-15 \mathrm{~min}$

$30-32^{\circ} \mathrm{C} 30-35 \mathrm{~min}$

$30-32^{\circ} \mathrm{C}$ then warm to $38^{\circ} \mathrm{C}$; $\mathrm{pH}$ should fall, approx $1 \frac{1 / 2 \mathrm{~h}}{}$

\section{$38^{\circ} \mathrm{C}$}

6,1-6,2 at moulding cation/turning of cheeses

11. Removing cheeses from cheese moulds

$\Rightarrow 12$. Salting of cheeses in brine

13. Maturation; mould development and ripening

\section{$20-28^{\circ} \mathrm{C}$}

\section{$\left(\frac{20}{20}\right.$}

$<5,3 \mathrm{pH}-24 \mathrm{~h}$<smiles>O=C1CCCCC1</smiles>

Approx $12^{\circ} \mathrm{C}, 220^{\circ} \mathrm{Be}$, approx $2 \mathrm{~h} / \mathrm{kg}$ cheese

Mould development $11-12^{\circ} \mathrm{C}, 95 \% \mathrm{RH}$ (relative humidity) for 3 weeks. Cheese is packaged and then ripened at $6^{\circ} \mathrm{C}$ to desired ripeness.

Figure 2 shows an example of a flow diagram for making White Caprin (a semi-soft rennet cheese). The method is taken more or less directly from Eldrimner's guidelines for cheese-making ${ }^{16}$.

${ }^{16} \mathrm{http} / / /$ www.eldrimner.com//1685.rapporter_bocker.html och http://www.slv.se/sv/grupp2/Livsmedelsforetag/Branschriktlinjer1/Guide-till-god-hygienisk-praxis-vid-hantverksmassig-tillverkning-av-ost-och-andra-mjolkprodukter-och-vagledning-i-eget-HACCP-arbete---Eldrimner-Nationelltresurscentrum-for-mathantverk/ 


\section{Hazard analysis}

Consider what hazards may be associated with each step in the flow diagram. Indirect steps in the process, such as moving the cheese from one place to another, should also be included in the hazard analysis. They should be included in the closest step and assessed together with that step. Suggestions of microbiological and chemical hazards can be found on the website of the National Food Administration (www.slv.se) ${ }^{17}$.

The hazards can be categorised as follows:

- M: Microbiological hazards - presence, development or contamination. The latter involves the transmission of pathogenic micro-organisms such as Listeria monocytogenes, Staphylococcus aureus, Salmonella or verotoxin-producing E.coli (VTEC) EHEC).

- C: Chemical hazards such as the presence of or contamination by remainders of medicine, cleansing agents or disinfection agents.

- P: Physical hazards, such as the presence of or contamination by physical objects such as fragments of glass or metal.

An additional hazard group is allergens. This group is often categorised as a chemical hazard. All cheese contains milk protein, to which some people are allergic, but other ingredients in cheese, such as spices and other additives can be allergenic. Careful listing of all ingredients is therefore essential. See more on this subject in "Handbook for the food industry and food distributors on allergies and other hypersensitivity - the management and labelling of foodstuffs" ${ }^{18}$.

\section{Preventive measures}

For each hazard a list of preventive measures should be made. This can, for instance, include production procedures or cleaning procedures. Many of these can be found under the heading "Prerequisite programme". A more detailed description of preventive measures can be found in the worksheets ${ }^{19}$ in Eldrimner's guidelines for cheese-making. The worksheets describe hazards, preventive measures, monitoring and immediate and future corrective measures for each step in the process.

\section{Hazard assessment and identification of critical control points}

Whether the hazard is considered to be a critical control point, a control point, part of the critical prerequisite programme or simply part of the prerequisite programme depends on how serious a threat to the consumer's health it represents and the probability of the hazard occurring at each specific step of the production process. Hazards

\footnotetext{
${ }^{17}$ http://www.slv.se/sv/grupp2/Livsmedelsforetag/Livsmedelsburna-halsofaror/

$18 \mathrm{http}$ ://www.slv.se/upload/dokument/livsmedelsforetag/branschriktlinjer/branschriktlinjer_allergi_slutversion_2005_05_17.pdf samt http://www.slv.se/upload/dokument/risker/allergi/Andringsblad\%20 mars\%202009.pdf

19 http://www.eldrimner.com//1685.rapporter_bocker.html och

http://www.slv.se/sv/grupp2/Livsmedelsforetag/Branschriktlinjer1/Guide-till-god-hygienisk-praxis-vidhantverksmassig-tillverkning-av-ost-och-andra-mjolkprodukter-och-vagledning-i-eget-HACCP-arbete---Eldrimner-Nationellt-resurscentrum-for-mathantverk/
} 
that both represent a serious threat and where the probability of them occurring is high must be carefully controlled (shall be identified as critical control points, see Figure 3), as they represent a high risk factor (consequence) because they are pathogenic. The seriousness of the hazard and its probability are judged separately for each step of the production process, but it is the combination of these two factors that decides whether the hazard represents a risk to the consumer. This can be seen from the position of the hazard in the table in Figure 3.

In the "Guidelines for the hygienic production of milk products", the categories below are used to identify the critical control points. The guidelines produced by Swedish Dairy Association provide a ranking scale for how serious and probable a hazard is judged to be. It can be summarised as follows:

\section{Seriousness}

Marginal (A): The presence of a hazard in a product and the consumption of the product will cause rise to no or only very mild illness. A physical and/or chemical effect that only causes mild injury.

Critical (B): The presence of a hazard in a product and the consumption of the product may cause rise to injury or mild illness, for example fever, vomiting, stomach ache or diarrhoea. These symptoms may not in any way become serious. A physical or chemical effect that causes injury.

Catastrophic (C): The presence of a hazard in a product and the consumption of the product will cause serious illness (high fever, vomiting, diarrhoea, damage to the nervous system, coma or death). A physical or chemical effect that causes serious injury.

\section{Probability}

Improbable (1) - (>10 years): It is considered to be improbable that the hazard will occur. The knowledge and experience of the members of the HACCP team, who are not only from the production place itself but also include, for example, representatives from the trade association, colleagues etc. or from external bodies, such as authorities or food research institutes, can confirm that the hazard occurs less than once every ten years.

Rare (2) - (1-10 years): It is considered to be likely that the hazard may occur. The members of the HACCP team, who are not only from the production place itself but also include, for example, representatives from the trade association, colleagues etc. or from external bodies, such as authorities or food research institutes, may have experience of the occurrence of the hazard or have warned of the possibility of it occurring.

Sometimes (3) - (1 year - 1 month): It is considered to be likely that the hazard may occur. The members of the HACCP team, who are not only from the production place itself, but also include, for example, representatives from the trade association, colleagues etc. may have experience of the hazard occurring or of measures having been taken to prevent the occurrence of the hazard at least once a year. External bodies may also have introduced legislation to ensure that preventive measures are taken to control the hazard. 
Often (4) - ( 1 month): It is considered to be extremely likely that the hazard may occur. The members of the HACCP team, who are not only from the production place itself, but also include, for example, representatives from the trade association, colleagues etc. may have experience of the hazard occurring or of measures having been taken to prevent the occurrence of the hazard. External bodies may also have introduced legislation to ensure that preventive measures are taken to control the hazard.

The combination of seriousness and probability is shown in Figure 3 below.

\begin{tabular}{|c|c|c|c|c|}
\hline \multicolumn{5}{|l|}{ Seriousness } \\
\hline Catastrophic C & $\begin{array}{l}\text { Critical Control } \\
\text { Point }(C C P) \\
\text { Control Point }(C P) \\
\text { Prerequisite } \\
\text { programme }(P P)\end{array}$ & $\begin{array}{l}\text { Critical Control } \\
\text { Point }(C C P) \\
\text { Control Point }(C P) \\
\text { Prerequisite } \\
\text { programme }(P P)\end{array}$ & $\begin{array}{l}\text { Critical Control } \\
\text { Point }(C C P) \\
\text { Control Point }(C P) \\
\text { Prerequisite } \\
\text { programme }(P P)\end{array}$ & $\begin{array}{l}\text { Critical Control } \\
\text { Point }(C C P) \\
\text { Control Point }(C P) \\
\text { Prerequisite } \\
\text { programme }(P P)\end{array}$ \\
\hline Critical B & Irrelevant & $\begin{array}{l}\text { Critical Control } \\
\text { Point }(=C C P) \\
\text { Control Point }(C P) \\
\text { Prerequisite } \\
\text { programme }(P P)\end{array}$ & $\begin{array}{l}\text { Critical Control } \\
\text { Point }(=C C P) \\
\text { Control Point }(C P) \\
\text { Prerequisite } \\
\text { programme }(P P)\end{array}$ & $\begin{array}{l}\text { Critical Control } \\
\text { Point }(=C C P) \\
\text { Control Point }(C P) \\
\text { Prerequisite } \\
\text { programme }(P P)\end{array}$ \\
\hline \multirow[t]{3}{*}{ Marginal A } & Irrelevant & Irrelevant & $\begin{array}{l}\text { Prerequisite } \\
\text { programme (PP) }\end{array}$ & $\begin{array}{l}\text { Prerequisite } \\
\text { programme (PP) }\end{array}$ \\
\hline & $\begin{array}{l}1 \\
\text { Improbable } \\
(>10 \text { years) }\end{array}$ & $\begin{array}{l}2 \\
\text { Rare } \\
(1-10 \text { years })\end{array}$ & $\begin{array}{l}3 \\
\text { Sometimes } \\
\text { (1 year-1 month) }\end{array}$ & $\begin{array}{l}4 \\
\text { Often } \\
\text { (1 } 1 \text { month) }\end{array}$ \\
\hline & \multicolumn{4}{|c|}{ Probability } \\
\hline
\end{tabular}

Figure 3. Model for the relationship between seriousness and probability when identifying a Critical Control Point (CCP), Control Point $(C P) \star$ and Prerequisite Programme (PP).

* Preventive measures in activities that are identified as critical control points are usually combined with a good prerequisite programme. Very important prerequisite programme measures, which are on the border to being critical control points are sometimes known as critical prerequisite programme measures Control points. Critical prerequisite programme measures are also sometimes known as control points. Irrespective of name, these last measures are usually monitored, where possible, almost as carefully as critical control points.

\section{Control diagrams - a summary of the critical control points and their monitoring}

The steps in the production process that are identified as critical control points are carefully monitored using monitoring schedules, verification and documentation.

\section{Critical Control Points (CCP)}

If a hazard can be regulated at a later stage of the production process, it is at the later stage that it will be categorised as a critical control point. A rule of thumb is that if the critical limit of a control point is exceeded, control over the process will be lost. If that occurs, the product must be discarded, or, if that is still possible, the process must be adjusted. The reason that the critical limit was exceeded must be examined, corrective measures must be taken, and the HACCP plan for the product in question must be revised. 


\section{Critical Limits}

A critical limit is specified for each preventive measure. An example of a critical limit for the pasteurisation of milk may be $63^{\circ} \mathrm{C}$ for 30 minutes. But it may also be something such as a visual control that an allergenic product is correctly labelled.

\section{Monitoring}

An essential part of HACCP is a program of observations or measurements performed at each critical point to ensure compliance with specified critical limit. Observations or measurements must be able to detect loss of control at critical points and provide information in time for corrective action to be taken. Observations or measurements can be made continuously or intermittently. When observations or measurements are not continuous, it is necessary to establish a frequency of observations or measurements which provides reliable information.

\section{Corrective measures}

The steps that are designated as critical control points should be monitored according to a well-defined schedule, be verified and documented. The monitoring should be followed-up through the documentation of critical limits, the careful following of monitoring schedules and the implementation of corrective measures (at the time and in the future). Corrective measures include finding the reason for why things went wrong, dealing with the product in question and checking and possibly revising the HACCP plan. An example of the monitoring process for pasteurising can be found in the guidelines "Monitoring of heat treatment equipment for milk and milk products" ${ }^{20}$. The programme ${ }^{21}$ includes a description of the methods, the frequency of the observations, how they are registered and also identify every CCP. It should answer the following questions;

- Who is responsible for monitoring and control?

- When should the monitoring and control take place?

- How should the monitoring and control take place?

Food producers are always responsible for their products. If there are a number of employees at a dairy, there should be a system that shows who is responsible for the various steps in the process, for ensuring the safety of the product and that its labelling provides the correct information.

\section{Validation}

To be certain that the cheese produced can be eaten without any health risk to the consumers, the producer's hygiene and monitoring schedules must be validated (be declared validwill it be safe if I do like this?) before a new product is launched. The producer must provide evidence that shows that the production process will result in a safe cheese. Validation can be carried out by an external expert who is familiar with the sector and who can check the producer's working conditions, raw materials, work routines and own control etc. in order to be able to declare the process (HACCP plan) valid. Alternatively, or in addition to this,

\footnotetext{
${ }^{20} \mathrm{http}: / /$ www.slv.se/upload/dokument/livsmedelsforetag/vagledningar/Kontroll_av_varmebehutrustn_ mjolk_\%20mjolkprod.pdf

${ }^{21}$ http://ec.europa.eu/food/food/biosafety/hygienelegislation/guidance_doc_haccp_sv.pdf
} 
information can be taken from well-known, accepted scientific literature, guidelines and other sources. For example, to find out whether different sorts of pathogens thrive in different environments associated with a certain product or process, prognosis models $\mathrm{s}^{22,23} \mathrm{can}$ be used, such as the Pathogen Modeling Program ${ }^{24}$ or Combase ${ }^{25}$.

\section{Verification}

It is important to verify that scheduled activities take place and that the validated hygiene and monitoring routines are followed. Various types of follow-up methods can be employed, such as checking that the validated working schedule is followed (everyone carries out the work in the same way), own control takes place and that the results are satisfactory. It is especially important that the producer regularly verifies that the values at the critical control points are satisfactory, for example, the $\mathrm{pH}$ when cheesemaking, which is essential to the production process of the different types of cheese. Taking tests and making microbiological analyses are further measures that can verify that the level of different microbiological hazards is satisfactory. See more on this subject under the heading "Verification through testing" and in Appendix 4.

\section{Example}

Under the headings "Critical control points and control points in cheese-making with pasteurised milk" and "Critical control points and control points in cheesemaking with unpasteurised milk" examples and hints are given for the monitoring, measures, documentation and verification of a number of critical control points associated with cheese-making. For instance under the heading "Critical control points and control points in cheese-making with pasteurised milk" there is an illustration of an example of a control card.

\footnotetext{
22 Personal communication 29th May 2009, Roland Lindqvist, National Food Administration

${ }_{23}$ Bilaga 4: Sammanfattning av symposiet "safety Issues of Raw Milk Cheese" i Bryssel 2008-12-11-12,

Ann-Charlotte Steneryd. Falkenberg Miljö- och hälsoskydd 2009

${ }^{24} \mathrm{http}: / /$ www.sssp.dtuaqua.dk/ and http://www.ars.usda.gov/services/docs.htm?docid=6786

25 http://www.combase.cc/browsw.html
} 


\section{Production}

Figure 2 illustrates the various steps in cheese-making in a flow diagram. The raw materials required in cheese-making are milk, rennet, starter culture, other microorganisms, salt and, finally, packaging material.

\section{Raw materials}

The flow chart shows at which stage of the production the raw materials are incorporated into the process. Raw materials that are bought externally must have a product specification that ensures that they are free from the possible hazards they may represent.

\section{Cooling of milk prior to cheese-making}

When milk is stored under refrigeration prior to cheese-making, the temperature and periods of storage specified in the food legislation must be followed. The regulations for cooling and storage after milking can be found under EC Regulation no. 853/2004 (Figure 4) ${ }^{26}$.

“2. Immediately after milking, milk must be held in a clean place designed and equipped to avoid contamination. It must be cooled immediately to not more than $8^{\circ} \mathrm{C}$ in the case of daily collection, or not more than $6^{\circ} \mathrm{C}$ if collection is not daily.

3. During transport the cold chain must be maintained and, on arrival at the establishment of destination, the temperature of the milk must not be more than $10^{\circ} \mathrm{C}$.

4. Food business operators need not comply with the temperature requirements laid down in points 2 and 3 if the milk meets the criteria provided for in Part III and either:

(a) the milk is processed within 2 hours of milking; or

(b) a higher temperature is necessary for technological reasons related to the manufacture of certain dairy products and the competent authority so authorises."

Figure 4. From EC Regulation no. 853/2004, Annex III Specific Requirements, Section IX: Raw milk and dairy products, Chapter I: Raw milk - primary production, II Hygiene on milk production holdings, B items 2-4.

The regulations for storage in the dairy prior to cheese-making can also be found under EC Regulation no. 853/2004 (Figure 5)

“I. Temperature Requirements

1. Food business operators must ensure that, upon acceptance at a processing establishment, milk is quickly cooled to not more than $6^{\circ} \mathrm{C}$ and kept at that temperature until processed.

2. However, food business operators may keep milk at a higher temperature if:

(a) processing begins immediately after milking, or within 4 hours of acceptance at the processing establishment; or

(b) the competent authority authorizes a higher temperature for technological reasons concerning the manufacture of certain dairy products."

Figure 5. From EC Regulation no. 853/2004, Annex III Specific Requirements, Section IX: Raw milk and dairy products, Chapter II: Requirements concerning dairy products

I. Temperature requirements, items 1-2

${ }^{26}$ http://eur-lex.europa.eu/LexUriServ/LexUriServ.do?uri=CONSLEG:2004R0853:20100715:EN:PDF 
One of the disadvantages associated with long refrigeration is that calcium is gradually transferred from the casein micelle to the milk serum? This reduces the cheese yield. Another disadvantage is that psychotrophic bacteria (which are a threat to the product) can multiply in the milk and if there are Listeria bacteria, they can also thrive under these conditions.

\section{The cheese-making process}

The nutrients in milk (fats and protein) become concentrated during the cheese-making process, as rennet is used to coagulate the milk and the whey is drained away. Lactic acid bacteria are introduced to the milk in order for the cheese-making process to function. These acidify the cheese and make it possible to mature the product.

Cheese-making can be divided up into a number of steps (see Figure 2):

1. The milk is received at the dairy and stored. Follow the food legislation with regard to the recommended temperature and period of storage.

2. If the milk is to be pasteurised, warm it to $63^{\circ} \mathrm{C}$ for 30 minutes. See that the milk is stirred as it is being warmed, so that all the milk reaches the right temperature for pasteurisation. Pasteurisation can also take place at $72^{\circ} \mathrm{C}$ for 15 seconds or other combinations of time and temperature that have the equivalent effect.

3. The required temperature for cheese-making is $30-32^{\circ} \mathrm{C}$. This means that if the milk has been cooled, it needs to be warmed and the pasteurised milk needs to be cooled to the required temperature $\left(30-32^{\circ} \mathrm{C}\right)$ before the lactic acid starter culture and mould spores (if desired) are added.

4. The starter culture is added, approx. $0.5-2 \%$ of the quantity of milk if an active starter is used.

5. Mould spores are added, for instance white mould (penicillium candidum) or blue mould (penicillium roqueforti). The dosage varies from producer to producer.

6. Pre-maturation

During the pre-maturation process, the lactic acid culture adapts itself to the milk and starts to transform lactose into lactic acid.

7. Addition of rennet/coagulation

Rennet is added and the chymosin in the rennet coagulates the milk. The milk sets as a solid.

8. Cutting the curd and scalding

When the curd is cut the solids are cut with a sharp knife or a wire cutter, so that the whey can be separated from the curds. Cutting the curd should not take more than 10 minutes. The hardness of the cheese is determined in the cutting process. For a soft cheese, the curd should be cut into large cubes and for a hard cheese, into small cubes. After cutting, the curds and whey are stirred carefully for $10 \mathrm{~min}$ utes. This is called pre-stirring. If a hard cheese is to be made the curds and whey must be heated gradually (scalding) to $380 \mathrm{C}$ or more. The curds and whey must be stirred during the scalding and the temperature should not be raised more than $2^{\circ} \mathrm{C}$ per 5 minutes. After the scalding, the curds and whey may need to be stirred a little longer before they are ready for draining and moulding. 
Throughout this step the temperature, consistency and $\mathrm{pH}$ of the curds must be checked regularly. If the $\mathrm{pH}$ does not decrease as much as expected, it may be necessary to extend the period of time in the cheese vat and the acidification may need to be activated by stirring more slowly or possibly letting the curds sink in the whey without stirring for short periods until the desired $\mathrm{pH}$ is achieved. If, on the other hand, the $\mathrm{pH}$ decreases too fast in relation to the moisture content of the curds or its consistency (the $\mathrm{pH}$ and the moisture content of the curds always need to be carefully controlled during cheese-making) the curds and whey should be stirred faster and the temperature should be raised a little. This speeds up the process of expelling moisture from the curds before the $\mathrm{pH}$ has decreased too much.

9. Moulding/acidification

When the correct $\mathrm{pH}$ is achieved, the curds can be taken out of the vat and placed in a cheese mould that is suitable for the type of cheese in question.

10. Draining/further acidification/turning

The cheese should be turned at regular intervals during the first 4 hours. Some cheeses are placed in a press in between the turning.

11. Removal from cheese moulds

12. Dry salting/placing in brine

After one day at room temperature, the cheeses are salted. This can be done by dry salting or by placing them in brine. The $\mathrm{pH}$ can be measured at this stage, which is known as "pH after 24 hours" or "final pH".

13. Maturation

Maturation can involve mould development, warm maturation and ripening.

Eldrimner's guidelines for cheese-making "Prerequisite programmes and working schedules" includes a useful chapter on the maturing of cheese ${ }^{27}$.

${ }^{27}$ http://www.eldrimner.com//1685.rapporter_bocker.html och http://www.slv.se/sv/grupp2/Livsmedelsforetag/Branschriktlinjer1/Guide-till-god-hygienisk-praxis-vid-hantverksmassig-tillverkning-av-ost-och-andra-mjolkprodukter-och-vagledning-i-eget-HACCP-arbete---Eldrimner-Nationellt-resurscentrum-for-mathantverk/ 


\section{Documentation of cheese-making}

A step-by-step record of the process should be kept when making cheese. The record sheet should include:

- The date of production/batch number (if a number of batches of the same type of cheese are made the same day),

- The name of the cheese,

- The type of milk (from which species, if more than one sort of milk is used),

- The amount of milk in every batch,

- Length of storage in milk tank if this varies,

- Dosage of starter culture (which type if this varies) and of rennet,

- Type and dosage of mould spores used, if any,

- Documentation of the temperature and time that the different steps take place

- In some cases the $\mathrm{pH}$ values so that the rate of acidification during the cheesemaking process can be followed,

- Unexpected events, if any.

The record can be kept in a book or on separate sheets (an example of these can be found as an appendix in Eldrimner's guidelines for cheese-making "Guidestart") 28 . One disadvantage of writing on separate sheets is that it is easy to lose track of them. The illustration below shows an example of a record sheet in a book. This documentation is an important part of the traceability and must be kept.

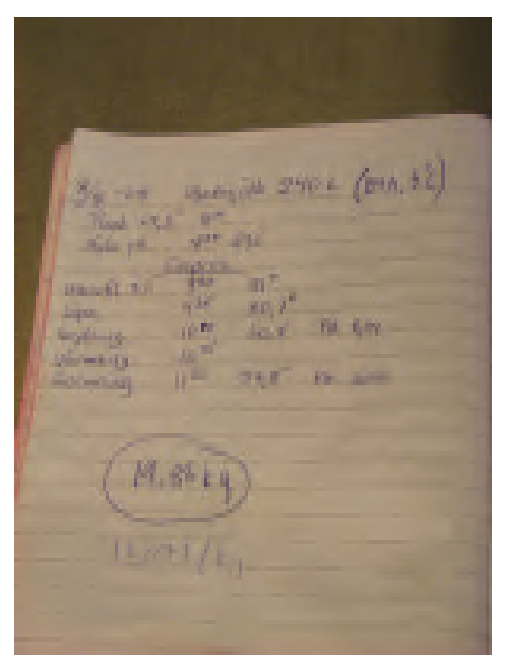

Illustration 1. Example of a record sheet for cheese-making.

\footnotetext{
${ }^{28}$ http://www.eldrimner.com//1685.rapporter_bocker.html och http://www.slv.se/sv/grupp2/Livsmedelsforetag/ Branschriktlinjer1/Guide-till-god-hygienisk-praxis-vid-hantverksmassig-tillverkning-av-ost-och-andra-mjolkprodukter-och-vagledning-i-eget-HACCP-arbete---Eldrimner-Nationellt-resurscentrum-for-mathantverk/
} 
Hint

\section{Commercial starter culture}

A starter culture is very important in cheese-making. Different methods of obtaining a starter culture are described in Eldrimner's guidelines for cheese-making "Prerequisite programmes and working schedules". By using a live culture instead of a freeze-dried one, the possibility of undesirable micro-organisms developing in the cheese-making process can be reduced. The freeze-dried culture must first go through a lag phase, which means that it will take a while before it starts to multiply, whereas the live culture can start multiplying almost as soon as it is added to the cheese vat. Another factor that influences acidification, and thus the safety of the cheese, is the dosage of the starter culture. The dosage of the starter culture can be $0.2-5 \%$ of the quantity of milk used ${ }^{29}$. In Swedish cheese-making it is usual to add a dosage of starter culture that is $0.5-2 \%$ of the quantity of milk used ${ }^{30}$. If a dosage of $0.2 \%$ starter culture is used instead of $2 \%$, a smaller amount of starter bacteria will be added to the milk.

The following rule of thumb can give an indication of how the culture will multiply: There will be 10 times as many bacteria after 3.3 generations, as 2 to the power of $3.3=10$.

If one assumes that the generation time (binary fission time) for lactic acid bacteria is 30 minutes (but it can vary greatly depending on the temperature and type of culture used) it will take approx. 1 hour and 40 minutes $^{31}$ for a dosage of $0.2 \%$ to reach the same level of bacteria as a dosage of $2 \%$. The lower dosage can be used if, for instance, a slow acidification is required at the start of the cheese making process, but it also increases the risk level, if there should be pathogenic bacteria in the milk. To make a live starter culture, freeze-dried culture or a small amount of live culture is inoculated into cooled pasteurised milk, which before being cooled is heated to $90^{\circ} \mathrm{C}$ (cf. $84^{\circ} \mathrm{C}$ for high pasteurisation) for 20 minutes. This results in the following:

- bacteria and bacteriophages die

- proteins are to some extent decomposed and

- certain bacteria-inhibiting substances, such as lactoperoxidase and immunoglobulins are broken down.

While propagating the culture it is important to employ an optimal time period and temperature. Mesophilic cultures should be propagated at room temperature for 18 hours \pm 2 hours and thermophilic cultures should be propagated at $45^{\circ} \mathrm{C}$ for 4 hours \pm 0.5 hours. After the given time period the $\mathrm{pH}(4.4-4.5)^{32}$, consistency, flavour and appearance of the culture should be checked.

By tasting the culture regularly, changes that are due to an imbalance between different strains or the presence of unwanted bacteria can be discovered. The activity level of the culture can be estimated by carrying out an activity test.

\footnotetext{
29 http://www.eldrimner.com//1685.rapporter_bocker.html och http://www.slv.se/sv/grupp2/Livsmedelsforetag/Branschriktlinjer1/Guide-till-god-hygienisk-praxis-vid-hantverksmassig-tillverkning-av-ost-ochandra-mjolkprodukter-och-vagledning-i-eget-HACCP-arbete---Eldrimner-Nationellt-resurscentrum-for-mathantverk/

${ }^{30}$ Cheese, Chemistry, Physics and Microbiology, 3:ed, Fox, P,F., Mcsweeney, P.L.H., Cogan, T,M., Guinee, T.P., Elsevier 2004. Sid 10.

${ }^{31}$ Från mjölk till mejeriprodukter, ost, Livsmedelsbranschernas yrkesnämnd. Brevskolan, 1982, ISBN:

91-574-0302-3

32 Personal communication 18th May 2009, Roland Lindqvist, National Food Administration
} 
An activity test can be carried out as follows:

High pasteurised milk is inoculated with $3 \%$ lactic acid culture and is kept at a temperature of $30^{\circ} \mathrm{C}$ for 4 hours.

- The increase in titratable acidity ${ }^{33}$ is measured by titrating the sample before and after 4 hours. The increase in titratable acidity should be $16^{\circ} \mathrm{SH}$, which is the equivalent of $40^{\circ}$ Th (Thörner degrees), if the culture has an acceptable level of activity.

- The $\mathrm{pH}$ can also be measured to give an indication of the activity, but it is important to be aware that this does not give a comprehensive view of the level of acidification activity. One reason for this is that acidification is made up of both the production of acid (can be seen in a decrease of the $\mathrm{pH}$ level and through titration), and of the production of carbon dioxide and flavour compounds (can be measured through titration). A measurement of the $\mathrm{pH}$ level does not give an exact measurement of the amount of acid that has been produced, as the $\mathrm{pH}$ depends on the buffering capacity of the milk, which varies from milk to milk.

More information about lactic acid cultures can be found in the sub-project presented in Appendix 5 "The cultivation and control of starter cultures in artisan cheesemaking"34.

Wild cultures

Sometimes when cheese is made with unpasteurised milk, wild cultures are used as a starter. These cultures are propagated by inoculating a commercial culture into unpasteurised milk. This results in a combination of the commercial culture and the wild lactic acid bacteria that may be present in the unpasteurised milk. A risk with this type of starter culture is that if the unpasteurised milk contains pathogenic bacteria, these may be propagated in the culture.

\footnotetext{
${ }^{33}$ Bilaga 6: Analysutrustning för gårdsmejerier, Ida Olofsson

${ }^{34}$ Bilaga 5: Dyrkning og kontroll av bruksyrekulturer vid handverksmessig osteproduksjon, Holmgeir Karlsson, Island
} 


\section{Taking care of brine}

When brine is used for salting the cheese, the cheeses are placed in saturated brine with a salinity of $21-23 \%$ in weight $(\mathrm{w} / \mathrm{v})$. Brine has proved to represent a hazard, as pathogenic bacteria can survive in brine ${ }^{35}$. It is therefore important to check the salinity of the brine regularly and to re-pasteurise it or replace it with new brine regularly. The salinity of the brine can be measured with an aerometer or a brine tester. Saturated brine has salt crystals at the bottom of the container and an aerometer will show a value of $22^{-} \mathrm{Be}$, which is the equivalent of $22 \%$ in weight of salt $(\mathrm{NaCl})^{36}$. A good practice to ensure that the brine is always saturated, is to add two percent of the weight of the cheeses, whenever cheeses are to be placed in the brine, which is the amount of salt that the cheeses are likely to absorb.

\section{Example}

If you are about to salt $20 \mathrm{~kg}$ of cheese, add $400 \mathrm{~g}$ (equivalent of approx. $3.1 \mathrm{dl}$ ) salt to the brine.

Dry salting reduces the risk of contamination, but it is harder to achieve a satisfactory result for large cheeses, which can result in an inferior product - both with regard to flavour and hygiene, as the salt helps to reduce the water activity in the cheese.

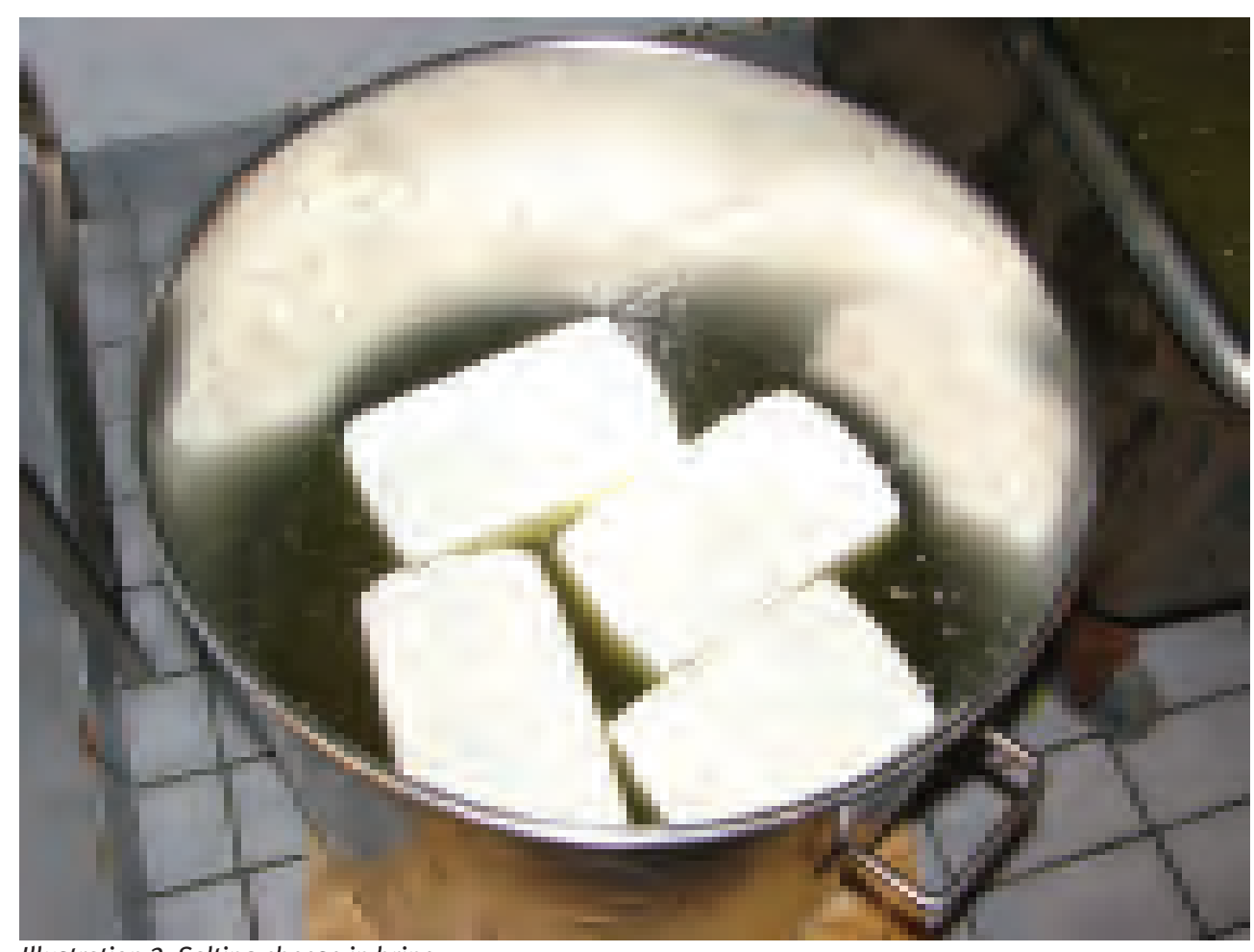

Illustration 2. Salting cheese in brine

${ }^{35}$ Survival of Salmonella typhimurium and Escherichia coli 0157:H7 in cheese brines. S.C. Ingham,Y-C Su, D.S.Sangenberg. International journal of Food Microbiology 61(2000) 73-79.

${ }^{36}$ Personal communication, Agneta Svensson, Arla Foods AB, Falkenberg. 


\section{Critical control points and control points in cheese making with pasteurised milk}

Common critical control points in cheese-making with pasteurised milk are the level of foreign substances in the milk (such as antibiotics, must be under the legal limit), pasteurisation and the rate of acidification. Control points can include the refrigeration temperature, the length of storage under refrigeration, the quality of the milk and the labelling of the products.

\section{The quality of the milk}

It is very important that there are no antibiotics in the milk, as they can represent a threat to the health of certain consumers. The presence of antibiotics can also cause problems in the acidification process during cheese-making. By respecting the milk withdrawal times for the antibiotics used, the contamination of milk by residues of antibiotics can be avoided. (See "Guidelines for the hygienic production of milk" and "Guidelines for the control of the quality of untreated milk". Both are published by the trade organisation Swedish Dairy Association ${ }^{37}$ ).

\section{Pasteurisation}

When making products from pasteurised milk, it is important to ensure that the pasteurisation has really been effective. Low pasteurised milk is used in cheese-making. The critical limits for low pasteurisation are $63^{\circ} \mathrm{C}$ for 30 minutes or $72^{\circ} \mathrm{C}$ for 15 seconds or another combination of time and temperature that has the same effect (see Eldrimner's guidelines for cheese-making "Prerequisite programmes and working schedules", Table $1^{38}$ ). This should be monitored each time that cheese is made and should be documented in the record sheet.

If the pasteurisation fails, corrective action must be taken immediately in the form of "re-pasteurisation", or the milk must be used to make another product, for instance a type of cheese that can be made from unpasteurised milk. In the latter case, the HACCP plan for this product must then be followed. This means monitoring the critical control points for the production of milk from unpasteurised milk. It is important to take into consideration the possible hazards related to the fact that the temperature may have in part reached the temperature for pasteurisation when the problem occurred. Maybe extra starter culture should be added to the milk.

A corrective measure for the future is to correct the problem before the next cheesemaking takes place. To verify the pasteurisation temperature, the dairy's cheese-

\footnotetext{
${ }^{37}$ http://www.slv.se/sv/grupp2/Livsmedelsforetag/Branschriktlinjer1/

${ }^{38} \mathrm{http}: / /$ www.eldrimner.com//1685.rapporter_bocker.html och http://www.slv.se/sv/grupp2/Livsmedelsforetag/Branschriktlinjer1/Guide-till-god-hygienisk-praxis-vid-hantverksmassig-tillverkning-av-ost-och-andramjolkprodukter-och-vagledning-i-eget-HACCP-arbete---Eldrimner-Nationellt-resurscentrum-for-mathantverk/

${ }^{39}$ Bilaga 6: Analysutrustning för gårdsmejerier, Ida Olofsson
} 
making thermometer should be checked regularly ${ }^{39}$. It is generally accepted that low pasteurisation is an effective bacteria-killing method, provided that the correct temperature and correct time period are employed for all of the milk, which means that it is important to stir the milk. As the time period is a critical factor, it is also important to have a reserve clock near to hand, if the ordinary clock should prove faulty.

It is important to keep to these time periods and temperatures in order to achieve a safe product without impairing the cheese-making properties of the milk. If the time period is too short or the temperature too low, the micro-organisms will not be eliminated. Too long a time and too high a temperature will spoil some of the milk's proteins and its cheese-making properties will be impaired. This may cause difficulties in draining off the whey, which will result in wet cheeses that can represent a microbial hazard.

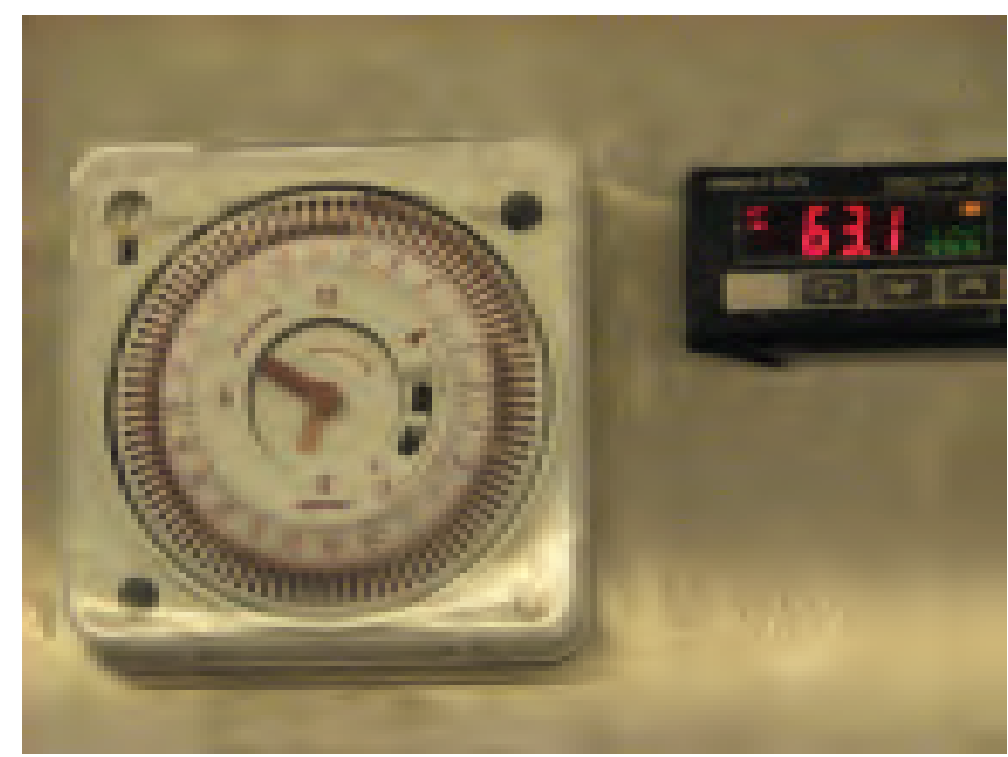

Illustration 3. Pasteurisation

\section{The rate of acidification when making cheese from pasteurised milk}

When making cheese from pasteurised milk, it is better to use a live starter culture (if a satisfactory one can be made) rather than freeze-dried starter culture (DVS). The starter culture should be added as soon as possible after the pasteurisation and cooling of the milk. During the cheese-making process and in the following 24-hour period, the cheese should be kept at a temperature $\left(20^{\circ} \mathrm{C}\right.$ or higher) that promotes beneficial acidification of the cheese. Some dairies have a draining room where the temperature is kept at $25-28^{\circ} \mathrm{C}$. If the temperature in the dairy is too low, problems such as insufficiently acidified cheeses and delayed acidification can arise. If the cheeses are kept at an optimal temperature (in relation to the starter culture used) for a sufficient time period, the lactic acid bacteria will have time to convert the lactose to lactic acid and flavour compounds. The $\mathrm{pH}$ should be measured regularly throughout the cheese-making process for each batch of cheese. During the cheese-making process, the $\mathrm{pH}$ should decrease, as this indicates that the lactic acid bacteria are multiplying as they should. If the $\mathrm{pH}$ does not decrease as expected, the acidification process in the cheese vat can be prolonged and activated by slowing down the stirring process or possibly by letting 
the curds sink in the cheese vat, without stirring, for short periods until the desired $\mathrm{pH}$ is achieved. The critical limit in the cheese vat, which shows that the acidification has reached the "correct" pH level, determines when the moulding process can begin, i.e. the curds can be lifted out of the vat and placed in the cheese moulds. By checking the $\mathrm{pH}$ after 24 hours, one can be certain that the process has continued to function successfully. A rule of thumb is that the $\mathrm{pH}$ in a cheese should be 5.3 after 6 hours at $30-37^{\circ} \mathrm{C}^{40}$. This means that the $\mathrm{pH}$ should remain under 5.3 after 24 hours too.

If the acidification has not worked at all, the only corrective measure possible is to discard the product, which should be done immediately. If the acidification has worked, but not been satisfactory, the maturation period can be extended. A corrective measure for the future is to find out the reason for the unsatisfactory acidification and remedy it before the next cheese-making takes place. Poor acidification can be due to the presence of the remains of washing-up detergent or antibiotics in the milk. Another reason can be that the starter culture is infected with bacteriophages or has a low level of activity.

The verification of measuring instruments for the acidification tests should be carried out by calibrating instruments such as the $\mathrm{pH}$ meter at least once a week and measuring with a control sample when necessary or at least four times per year ${ }^{41}$. All the measurements and measures carried out should be documented in the relevant report sheet or in the system for own control.

\section{Hint}

Below is an example of a control schedule for cheese-making with pasteurisation in a vat

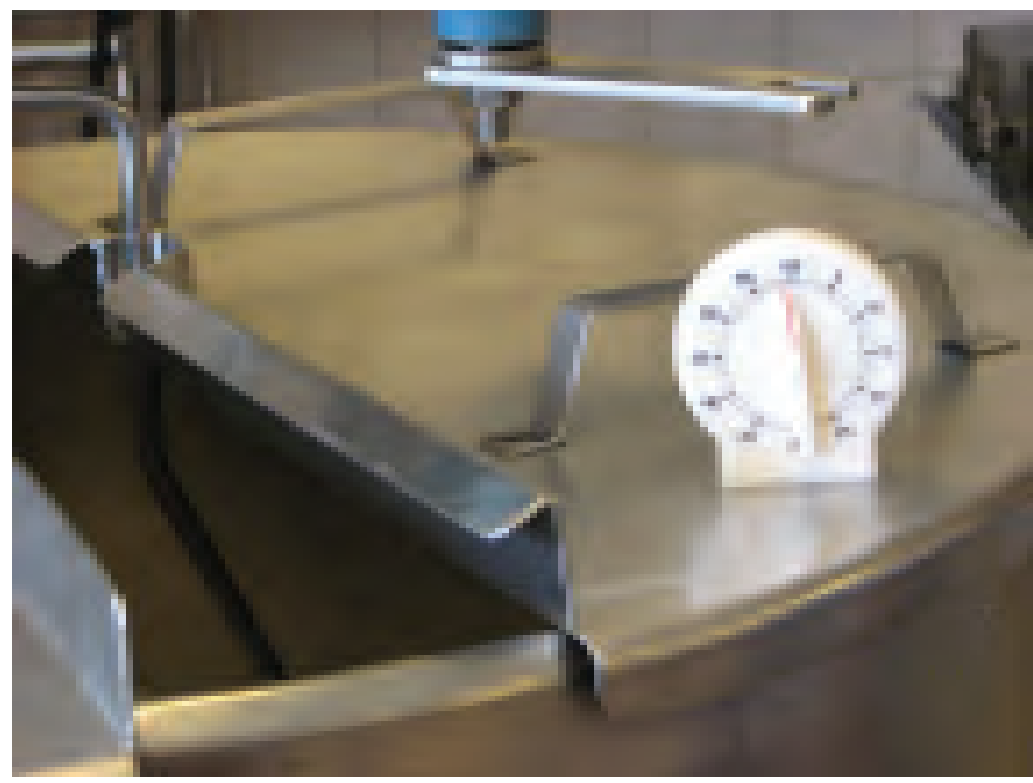

Illustration 4. Acidification during cheese-making

\footnotetext{
40 Cheese, Chemistry, Physics and Microbiology, 3:ed, Fox, P,F., Mcsweeney, P.L.H., Cogan, T,M., Guinee, T.P., Elsevier 2004. Page 287

${ }^{41}$ Bilaga 6: Analysutrustning för gårdsmejerier, Ida Olofsson
} 


\section{Tabell för pastörisering}

\begin{tabular}{|c|c|c|c|c|c|c|c|}
\hline \multirow[t]{2}{*}{ No } & \multirow[t]{2}{*}{ Activity } & \multirow{2}{*}{$\begin{array}{l}\text { Hazard - } \\
\text { from product } \\
\text { group's } \\
\text { hazard } \\
\text { analysis }\end{array}$} & \multicolumn{2}{|c|}{ Monitoring } & \multirow{2}{*}{$\begin{array}{l}\text { Corrective measure for } \\
\text { process and product }\end{array}$} & \multirow{2}{*}{$\begin{array}{l}\text { Documentation } \\
\text { What? } \\
\text { Where? } \\
\text { Who? }\end{array}$} & \multirow{2}{*}{$\begin{array}{l}\text { CCP verification } \\
\text { What? } \\
\text { Where? } \\
\text { Who? }\end{array}$} \\
\hline & & & $\begin{array}{l}\text { Measuring } \\
\text { method } \\
\text { Frequency } \\
\text { Who? }\end{array}$ & Critical Limit & & & \\
\hline & \multirow[t]{4}{*}{$\begin{array}{l}\text { Pasteuri- } \\
\text { sation }\end{array}$} & \multirow[t]{4}{*}{$\begin{array}{l}\text { M: } \\
\text { Ineffective } \\
\text { killing of } \\
\text { pathogens } \\
\text { Salmonella, } \\
\text { Staphylococ- } \\
\text { cus aureus, } \\
\text { Listeria } \\
\text { monocyto- } \\
\text { genes and } \\
\text { pathlogenic } \\
\text { E. coli EHEC/ } \\
\text { VTEC. }\end{array}$} & $\begin{array}{l}\text { Check time } \\
\text { period, } \\
\text { temperature } \\
\text { and stirrer } \\
\text { Each cheese- } \\
\text { making } \\
\text { Who? } \\
\text { Cheese- } \\
\text { maker * }\end{array}$ & $\begin{array}{l}\text { Keep } \\
\text { temperature } \\
\geq 63^{\circ} \mathrm{C} \text { and } \\
>30 \mathrm{~min} \\
\text { Stirrer } \\
\text { works }\end{array}$ & $\begin{array}{l}\text { Continued heat } \\
\text { treatment, so that the } \\
\text { correct combination of } \\
\text { time and temperature } \\
\text { is achieved or discard } \\
\text { the cheese or mature } \\
\text { cheese longer } \\
\text { Find out why control } \\
\text { was lost and take } \\
\text { measures so that it } \\
\text { will not happen in the } \\
\text { future } \\
\text { Who? } \\
\text { Cheese- maker * }\end{array}$ & $\begin{array}{l}\text { Temperatures, } \\
\text { starting time } \\
\text { and finishing } \\
\text { time when all } \\
\text { the milk is at } \\
63^{\circ} \mathrm{C} \\
\text { Note that } \\
\text { the stirrer is } \\
\text { functioning } \\
\text { correctly } \\
\text { In the cheese } \\
\text { journal } \\
\text { Who? } \\
\text { Cheese-maker * }\end{array}$ & \multirow{4}{*}{$\begin{array}{l}\text { Make sure that } \\
\text { everyone involved } \\
\text { in the production } \\
\text { process understands } \\
\text { the importance } \\
\text { of monitoring, } \\
\text { corrective measures } \\
\text { and documentation } \\
\text { (why everything must } \\
\text { function). } \\
\text { If more than one } \\
\text { person pasteurises, } \\
\text { all involved should } \\
\text { check x times a year } \\
\text { that they follow the } \\
\text { schedule (work in the } \\
\text { same way) and write } \\
\text { down that it is so. } \\
\text { New routines should } \\
\text { be changed in the } \\
\text { HACCP plan and } \\
\text { discussed with all } \\
\text { members of staff } \\
\text { Verification also take } \\
\text { place by testing i.g. } \\
\text { the processhygiene } \\
\text { (see Appendix } 4 \text { ). } \\
\text { Who? } \\
\text { The person } \\
\text { responsible for the } \\
\text { product (Responsible } \\
\text { for HACCP) }\end{array}$} \\
\hline & & & $\begin{array}{l}\text { Function } \\
\text { test of } \\
\text { thermometer } \\
\text { x times per } \\
\text { year } \\
\text { Who? } \\
\text { Cheese- } \\
\text { maker * }\end{array}$ & $\begin{array}{l}\text { It functions } \\
\text { satisfactory } \\
\text { and shows } \\
\text { the correct } \\
\text { temperature }\end{array}$ & $\begin{array}{l}\text { Calibration or replace } \\
\text { thermometer, keep a } \\
\text { functioning reserve } \\
\text { thermometer in } \\
\text { reserve } \\
\text { Who? } \\
\text { Cheese- maker * }\end{array}$ & $\begin{array}{l}\text { The function } \\
\text { test and } \\
\text { deviation (if } \\
\text { there is one) } \\
\text { shall be noted } \\
\text { in a suitable } \\
\text { place, possibly } \\
\text { in the cheese } \\
\text { journal } \\
\text { Who? } \\
\text { Cheese-maker * }\end{array}$ & \\
\hline & & & $\begin{array}{l}\text { Take the time } \\
\text { each time } \\
\text { cheese is } \\
\text { made } \\
\text { Who? } \\
\text { Cheese- } \\
\text { maker * }\end{array}$ & $\begin{array}{l}\text { The clock } \\
\text { used must } \\
\text { work and be } \\
\text { correct }\end{array}$ & $\begin{array}{l}\text { Adjust or replace } \\
\text { clock; have an extra } \\
\text { clock in reserve } \\
\text { Who? } \\
\text { Cheese- maker * }\end{array}$ & & \\
\hline & & & $\begin{array}{l}\text { Check that } \\
\text { the stirrer } \\
\text { works. } \\
\text { Should be } \\
\text { checked } \\
\text { every time } \\
\text { cheese is } \\
\text { made. } \\
\text { Who? } \\
\text { Cheese- } \\
\text { maker * }\end{array}$ & $\begin{array}{l}\text { Functions } \\
\text { correctly }\end{array}$ & $\begin{array}{l}\text { Repair or replace } \\
\text { stirrer. } \\
\text { Who? } \\
\text { Cheese- maker * }\end{array}$ & & \\
\hline
\end{tabular}

* The person responsible for cheese production 
Tabell för syrning (Acidification)

\begin{tabular}{|c|c|c|c|c|c|c|c|}
\hline \multirow[t]{2}{*}{ No } & \multirow[t]{2}{*}{ Activity } & \multirow{2}{*}{$\begin{array}{l}\text { Hazard - } \\
\text { from product } \\
\text { group's } \\
\text { hazard } \\
\text { analysis }\end{array}$} & \multicolumn{2}{|c|}{ Monitoring } & \multirow{2}{*}{$\begin{array}{l}\text { Corrective measure for } \\
\text { process and product }\end{array}$} & \multirow{2}{*}{$\begin{array}{l}\text { Documentation } \\
\text { What? } \\
\text { Where? } \\
\text { Who? }\end{array}$} & \multirow{2}{*}{$\begin{array}{l}\text { CCP verification } \\
\text { What? } \\
\text { Where? } \\
\text { Who? }\end{array}$} \\
\hline & & & $\begin{array}{l}\text { Measuring } \\
\text { method } \\
\text { Frequency } \\
\text { Who? }\end{array}$ & Critical Limit & & & \\
\hline & $\begin{array}{l}\text { Acidifi- } \\
\text { cation }\end{array}$ & $\begin{array}{l}\text { M: } \\
\text { A poor } \\
\text { propagation } \\
\text { of lactic acid } \\
\text { bacteria may } \\
\text { mean that } \\
\text { pathogens, } \\
\text { which may } \\
\text { have been } \\
\text { in the milk } \\
\text { (when making } \\
\text { cheese from } \\
\text { unpasteurised } \\
\text { milk) or curds } \\
\text { contaminated } \\
\text { with } \\
\text { pathogens } \\
\text { such as } \\
\text { Staphylo- } \\
\text { coccus } \\
\text { aureus and } \\
\text { Pathogenic } \\
\text { E. coli EHEC/ } \\
\text { VTEC, can } \\
\text { multiply } \\
\text { without } \\
\text { inhibition from } \\
\text { competetition } \\
\text { by lactic acid } \\
\text { bacteria. }\end{array}$ & $\begin{array}{l}\text { Check the } \\
\text { pH during } \\
\text { cheese- } \\
\text { making and } \\
24 \text { hours } \\
\text { after starting } \\
\text { cheese- } \\
\text { making, } \\
\text { Each cheese } \\
\text {-making } \\
\text { Who? } \\
\text { Cheese - } \\
\text { maker * }\end{array}$ & $\begin{array}{l}\mathrm{pH} \text { should } \\
\text { decrease, } \\
\text { and } \\
\text { according to } \\
\text { recipe } \\
\mathrm{pH}<5.3 \text { or } \\
\text { lower in } \\
\text { most cases }\end{array}$ & $\begin{array}{l}\text { Continued } \\
\text { acidification, so } \\
\text { that the correct } \\
\text { combination of time } \\
\text { and temperature is } \\
\text { achieved or discard } \\
\text { the cheese or mature } \\
\text { cheese longer } \\
\text { Find out why control } \\
\text { was lost and take } \\
\text { measures so that it } \\
\text { will not happen in the } \\
\text { future } \\
\text { Who? } \\
\text { Cheese- maker * } \\
\text { Calibration or replace } \\
\text { pH meter } \\
\text { Who? } \\
\text { Cheese- maker * }\end{array}$ & $\begin{array}{l}\text { pH at the given } \\
\text { times } \\
\text { In the cheese } \\
\text { journal } \\
\text { Who? } \\
\text { Cheese-maker * } \\
\\
\text { The function } \\
\text { test shall be } \\
\text { noted in a } \\
\text { suitable place, } \\
\text { possibly in the } \\
\text { cheese journal } \\
\text { Who? } \\
\text { Cheese-maker * }\end{array}$ & $\begin{array}{l}\text { Make sure that } \\
\text { everyone involved } \\
\text { in the production } \\
\text { process understands } \\
\text { the importance } \\
\text { of monitoring, } \\
\text { corrective measures } \\
\text { and documentation } \\
\text { (why everything must } \\
\text { function). } \\
\text { If more than one } \\
\text { person makes cheese, } \\
\text { all involved should } \\
\text { check x times a year } \\
\text { that they follow the } \\
\text { schedule (work in the } \\
\text { same way) and write } \\
\text { down that it is so. } \\
\\
\text { New routines should } \\
\text { be changed in the } \\
\text { HACCP plan and } \\
\text { discussed with all } \\
\text { members of staff } \\
\text { Verification also takes } \\
\text { place by testing i.g. } \\
\text { the processhygiene } \\
\text { (see Appendix } 4 \text { ). } \\
\text { Who? } \\
\text { The person } \\
\text { responsible for the } \\
\text { product (Responsible } \\
\text { for HACCP) }\end{array}$ \\
\hline
\end{tabular}

* The person responsible for cheese production 


\section{Critical control points and control points in cheese- making with unpasteurised milk}

Common critical control points when making cheese from unpasteurised milk are the quality of the milk, the rate of acidification and the time period that the cheese is matured. Control points can include the refrigeration temperature, the time period that the milk is stored under refrigeration, management of the brine and finally labelling of the product. Further information about the safety aspects of cheese-making with unpasteurised milk can be found in Appendix 3: Summary of symposium "Safety Issues of Raw Milk Cheese".

\section{The quality of the milk}

It is very important that there are no antibiotics in the milk, as they can represent a threat to the health of certain consumers. The presence of antibiotics can also cause problems in the acidification process during cheese-making. The values should be lower than the given limits for foreign substances. (See "Guidelines for the hygienic production of milk" and "Guidelines for the control of the quality of untreated milk". Both are published by the trade organisation Swedish Dairy Association ${ }^{42}$ ).

The bacteriological quality of the milk has great significance for cheese-making. The milk can be infected by poor hygiene when milking or by sub-clinical (not visible) mastitis (inflammation of the udder). When making cheese of unpasteurised milk it is important that the milk contains a minimum of pathogenic bacteria, as they can multiply during cheese-making.

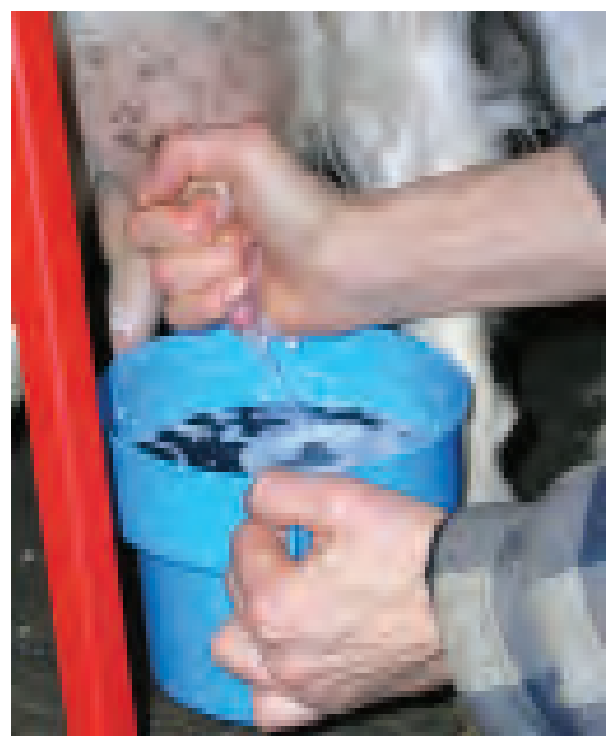

Illustration 5. Foremilking into a strip cup

${ }^{42}$ http://www.slv.se/sv/grupp2/Livsmedelsforetag/Branschriktlinjer1/ 
Subclinical or clinical mastitis causes milk with inferior protein quality, which gives a lower cheese yield ${ }^{43}$.

When milking, the following factors must be remembered:

- The teats, udder and other parts of the cow close to the udder must be clean.

- Do not use milk from cows with sores on their teats.

- Foremilk into a strip cup for a visual assessment of the milk. Use the strip cup for all animals. By foremilking, the milk that is in the teat is removed, which is the most likely to be contaminated.

- Do not use milk from animals that show symptoms associated with clinical mastitis (that have a temperature, are sluggish or have blood, flakes or clots in their milk). ${ }^{44}$

- Do not use milk from animals that are under medical treatment until after the withholding period.

- Work actively with udder health by measuring the somatic cell count in the milk in the tank at least once a month. ${ }^{45}$

In the case of subclinical mastitis, the animal does not have any visible symptoms and there is no clear indication in the milk, but bacteria may still be present in the milk.

According to EU regulations, the milk in the tank on a dairy farm with cows may not have a somatic cell count that exceeds 400,000 cells $^{46}$. There is no equivalent figure for sheep and goats, but 400,000 cells can give an indication of the acceptable level for these species too. Cows with a higher cell count than 150,000-200,000 should be checked to see if there are bacteria in their milk. If the cell count is estimated using a CMT test ${ }^{47}$, this is the equivalent of a two on the CMT scale. A CMT reaction of 1-2 can, however, be hard to identify, so a bacteriological test is recommended in the case of a CMT reaction over 2. It is harder to judge in the case of goat's milk. Nevertheless, a general recommendation is to carry out a bacteriological test in the case of a CMT value over 2. A more detailed description of indicators of mastitis in goats and cows can be found in Appendix 7: "Methods for discovering subclinical mastitis in goats"48. It should, however, be mentioned that Appendix 7 is based on a specific study, which is why the CMT limit in the study differs from the recommendations in these guidelines.

The cell count can also be measured with De Laval's cell counter (DCC), Portacheck SCC. For further details about analysis equipment, see Appendix 6 "Analysis equipment for farm dairies" ${ }^{49}$. Validation and verification of CMT-measurements can be carried out by sending parallel samples to a laboratory for cell count tests.

\footnotetext{
43 Mastitis in dairy production Current knowledge and future solutions. H.Hogeveen. ISBN:90 76998701

44 EC Regulation no. 853/2004, Annex III, Section IX, Chapter I

45 EC Regulation no. 853/2004, Annex III, Section IX, Chapter III

46 EC Regulation no. 853/2004, Annex III, Section IX, Chapter III

47 Bilaga 7: Metoder för att påvisa juverinfektion utan kliniska symtom hos get. Ylva Persson, SVA 2008

${ }^{48}$ Bilaga 7: Metoder för att påvisa juverinfektion utan kliniska symtom hos get. Ylva Persson, SVA 2008

49 Bilaga 6: Analysutrustning för gårdsmejerier, Ida Olofsson
} 


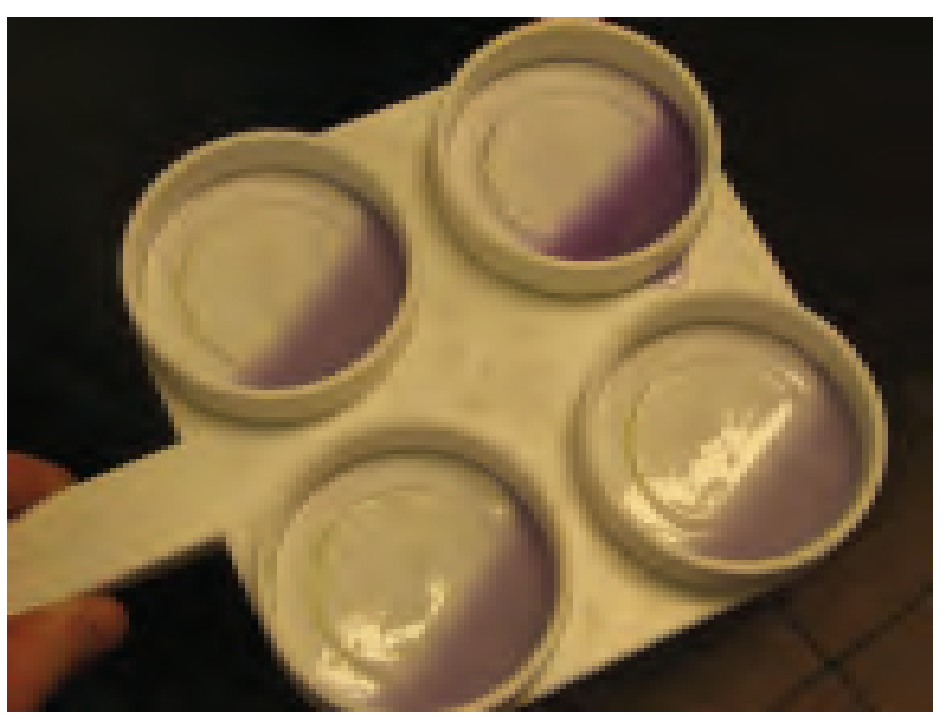

Illustration 6. CMT test of milk

A corrective measure is to refrain from using milk from these animals for cheese-making. When making cheese from unpasteurised milk, the cheese-making process must be adapted to take into account that there may be Staphylococcus aureus (S. aureus) in the milk. The following measures are ways of adapting the process to take this into account. These measures are also described in Appendix 8 "The occurrence and prevention of unwanted micro-organisms and impurities in small-scale dairying in Norway" ${ }^{20}$ :

- Use a live starter culture instead of a freeze-dried one. If a freeze-dried culture is used, it should first be activated by inoculating it into fresh or boiled, cooled milk and letting it stand for $1 / 2-1$ hour before using.

- S. aureus thrives best at a temperature of $37^{\circ} \mathrm{C}$. The milk should not, therefore, be warmed to a temperature exceeding $35^{\circ} \mathrm{C}$. If the curds and whey are warmed to over this temperature, a thermophilic culture should be added, in addition to the mesophilic culture, which can help to compete with the $\mathrm{S}$. aureus bacteria at temperatures over $35^{\circ} \mathrm{C}$.

- The use of a sufficient dosage of a fresh, live starter culture reduces the risk of S. aureus bacteria multiplying ${ }^{51}$.

- Keep to the recommended storage temperature, transport temperature, if relevant, and recommended time periods. If the milk might possibly be contaminated by $\mathrm{S}$. aureus bacteria, there is a risk that toxins may develop.

By carrying out a self-acidification test ${ }^{52}$ on the milk, the amount of lactic acid bacteria can be estimated. This should be done regularly, as the bacteria content of the milk varies throughout the year ${ }^{53}$. One can also make an estimation of the self-acidification propensity of the milk during cheese-making, as milk with a high self-acidification propensity will acidify faster during cheese-making than one with a low self-acidification

\footnotetext{
50 Bilaga 8: Forekomst og forebygging av uønska mikroorganismer og fremmedstoffer i småskala mjölkeforedling i Norge. Resurssentret, Sogn Jord og Hagebruksskule. Ragnhild Nordbo, Pascale Baudonnel, 2008

51 Stadkouders,J. 1986 The control of cheese starter activity. Netherlands Milk and Dairy Journal 40, 155-173

52 Bilaga 6: Analysutrustning för gårdsmejerier, Ida Olofsson

53 C. Callon, F.Duthoit, C Delbès, M. Ferrand, Y. LeFrileux, R. DeCrémoux, M-C Montel, Stability of microbial communities in goat milk during a lactation year: Molecular approaches, Systematic and applied microbiology 30(2007) 547-56
} 
propensity. This can be seen in a shorter setting time, faster hardening and better draining properties. A corrective measure that can be taken if the milk has poor selfacidification properties or if the curds and whey do not acidify satisfactorily during cheese-making is to add more starter culture in order to ensure a safe product.

A representative number of random samples of untreated milk taken from randomly selected milk production plants should be tested to check the total amount of bacteria and antibiotics in the milk. How this is done is described in EC Regulation no. $853 / 2004^{54}$.

The total number of bacteria in the milk should be measured twice a month ${ }^{55}$ and must meet the following requirements:

Untreated cow's milk

Untreated milk from other species
Total number of bacteria $\leq 100000 \mathrm{cfu} /$ $\mathrm{ml}^{*}$; individual measurements shall not exceed $300000 \mathrm{cfu} / \mathrm{ml}$.

Total number of bacteria $\leq 1500000$ (such as sheep and goat) $\mathrm{cfu} / \mathrm{ml}^{*}$; provided this milk is not to be used for the production of unpasteurised products. If this is the case $\leq 500000 \mathrm{cfu} / \mathrm{ml}^{*}$.

*Rolling geometric mean during a two-month period

In a Norwegian study ${ }^{56}$ on the occurrence and propagation of S. aureus bacteria in cheese-making, the results showed that if there were $\leq 100 \mathrm{cfu} / \mathrm{ml} \mathrm{S}$. aureus bacteria in the milk, a certain safety margin still existed and some variation in the acidification rate was still possible without there being a risk of exceeding the limits of $\mathrm{S}$. aureus bacteria (i.e. $\leq 100000 \mathrm{cfu} / \mathrm{ml}$ which is considered to be the limit for the production of toxins). If there were $\leq 200 \mathrm{cfu} / \mathrm{ml} \mathrm{S}$. aureus bacteria and satisfactory acidification, it always resulted in a safe product. However, when there were $\leq 500 \mathrm{cfu} / \mathrm{ml} \mathrm{S}$. aureus bacteria, the count of $\mathrm{S}$. aureus bacteria in the cheese was always too high.

The results of cell count tests and milk analyses, if made, should be noted in the cheese-making journal that is part of the dairy's own control system.

\footnotetext{
${ }^{54}$ EC Regulation no. 853/2004, Annex III, Section IX, Chapter III

${ }_{55}$ EC Regulation no. 853/2004, Annex III, Section IX, Chapter III

${ }^{56}$ Bilaga 8: Forekomst og forebygging av uønska mikroorganismer og fremmedstoffer i småskala mjölkeforedling i Norge. Resurssentret, Sogn Jord og Hagebruksskule. Ragnhild Nordbo, Pascale Baudonnel, 2008
} 
Things to remember regarding milking schedules and bacterial flora in milk When the bacteria level is low ( $5000 \mathrm{cfu} / \mathrm{ml})$, the microorganisms present are often dominated by micrococcus and streptococcus bacteria, which come from the skin of the teats. A high level of bacteria is often due to contamination from the deep litter or poorly cleaned udders. This often results in an increase of gram negative rods (including coli types) at the expense of micrococcus bacteria ${ }^{57}$.

\section{Storage temperature and storage time period for milk}

For more information about the legislation in this area, see under the heading "Cooling of milk for cheese-making”. When making soft rennet cheeses (such as Banonost, Hälsingeost and Kaffeost) the milk should not have been milked longer than 2 hours before cheese-making ${ }^{58}$. When making soft cheeses of unpasteurised milk (such as semi-soft and soft rennet cheeses or blue cheeses) the milk should not have been milked longer than 24 hours before cheese-making (two milkings) ${ }^{59}$. When making cheese from unpasteurised milk a starter culture should be added to the milk as soon as possible.

\section{Did you know that:}

Milk that is cooled to $15-21^{\circ} \mathrm{C}$ is dominated by mesophilic organisms such as Lactococcus och Ente-rococcus bacteria. Cooling to 4으 $\mathrm{C}$ will slow down the growth of most micro-organisms, but psychotrophic bacteria such as Pseudomonas, Flavobacterium and Acinetobacter will continue to multiply and dominate the bacterial population ${ }^{60}$. Pseudomonas is a type of bacteria that often has a negative affect on the appearance and flavour of cheeses.

\section{The rate of acidification when making cheese from unpasteurised milk}

Acidification takes place more slowly in unpasteurised than pasteurised milk. This can be for a number of reasons, such as competition from other bacteria, a certain amount of free oxygen, bacteria-inhibiting systems etc. Lactic acid bacteria from non-dairy environments often have a higher production of antimicrobial substances (bacteriocines) than strains that come from dairy environments or commercial cultures, but on the other hand they are less effective at acidifying milk ${ }^{61}$.

\footnotetext{
57 Dairy microbiology handbook, the microbiology of milk and milk products.R.K.Robinson. 3:e ed, Wiley 2002

58 http://www.eldrimner.com//1685.rapporter_bocker.html och http://www.slv.se/sv/grupp2/Livsmedelsforetag/Branschriktlinjer1/Guide-till-god-hygienisk-praxis-vid-hantverksmassig-tillverkning-av-ost-och-andramjolkprodukter-och-vagledning-i-eget-HACCP-arbete---Eldrimner-Nationellt-resurscentrum-for-mathantverk/ 59 Bilaga 8: Forekomst og forebygging av uønska mikroorganismer og fremmedstoffer i småskala mjölkeforedling i Norge. Resurssentret, Sogn Jord og Hagebruksskule. Ragnhild Nordbo, Pascale Baudonnel, 2008

${ }^{60}$ Cheese, Chemistry, Physics and Microbiology, 3:ed, Fox, P,F., Mcsweeney, P.L.H., Cogan, T,M., Guinee, T.P., Elsevier 2004. Page 287

${ }^{61}$ Microbes from raw milk for fermented dairy products. J.T.M. Wouters, E.H.E. Ayad, J Hugenholtz, G Smit. International Dairy Journal 12 (2002) 91-109
} 
The $\mathrm{pH}$ should decrease during cheese-making. If the $\mathrm{pH}$ does not decrease as expected, the period of acidification in the cheese vat can be extended, for instance by stirring more slowly or by letting the curds sink in the whey without stirring for short periods until the desired $\mathrm{pH}$ is achieved. The critical limit in the cheese vat, that shows that the acidification has reached the "correct" $\mathrm{pH}$ level, determines when the moulding process can begin, i.e. the curds can be lifted out of the vat and placed in the cheese moulds. By checking the $\mathrm{pH}$ after 24 hours one can be certain that the process has continued to function successfully. A rule of thumb is that the $\mathrm{pH}$ in a cheese should be 5.3 after 6 hours at $30-37^{\circ} \mathrm{C}^{62}$. This means that the $\mathrm{pH}$ should remain under 5.3 after 24 hours too.

If the acidification has not worked at all, the only corrective measure possible is to discard the product, which should be done immediately. If the acidification has worked, but not been satisfactory, the maturation period can be extended. (This does not help, however, if S.aureus toxin (poison) is present in the cheese.) A corrective measure for the future is to find out the reason for the unsatisfactory acidification and remedy it before the next cheese-making takes place. Poor acidification can be due to the presence of remains of washing up detergent or antibiotics in the milk. Another reason can be that the starter culture is infected with bacteriophages or has a low level of activity. As mentioned above, satisfactory acidification can be seen in the cheese-making process. This should be monitored each time cheese is made.

\section{Did you know that:}

In the sub-project "Summary of conference Safety Issues of Raw Milk Cheese" 63 there is a reference to an on-going project that aims to develop a cost-effective method for analysing pathogens in milk. Another project is working on developing a lactic acid starter culture that can prevent the propagation of pathogenic bacteria in cheese made from unpasteurised milk.

\section{Sufficient period of maturation}

As cheese is not a very favourable environment for bacteria propagation, it is assumed that any bacteria that may be in the milk will not survive a long period of maturation. Ripening alone is no guarantee of safety. It must be combined with preventive measures in the form of a good prerequisite programme. Certain types of cheese are intended for direct consumption and are not matured at all. They are known as fresh cheeses. The food safety of fresh cheeses cannot, therefore, be controlled by extending the period of maturation, but must instead be based entirely on a good prerequisite programme and critical control points that the producer has identified for this specific type of cheese.

\footnotetext{
${ }^{62}$ Cheese, Chemistry, Physics and Microbiology, 3:ed, Fox, P,F., Mcsweeney, P.L.H., Cogan, T,M., Guinee, T.P., Elsevier 2004.

${ }^{63}$ Bilaga 3: Sammanfattning av symposiet "safety Issues of Raw Milk Cheese" i Bryssel 2008-12-11-12, Ann-Charlotte Steneryd. Falkenberg Miljö- och hälsoskydd
} 


\section{Prerequisite programme}

\section{Education, personal hygiene, water and pest control}

Regulations regarding these matters can be found in the relevant legislation and recommendations in Sweden, Norway and Iceland. Further information about prerequisite programmes for cheese-making can be found in Eldrimner's guidelines for cheese-making "Prerequisite programme and working schedules" ${ }^{64}$.

\section{Cleaning}

\section{Cleaning and disinfection}

In the case of artisan cheese-making, it is better to employ effective cleaning measures without disinfection than disinfection without cleaning ${ }^{65}$. Systematic disinfection is not recommended for small-scale dairies, as it can impair the beneficial microbiological flora that exists in the dairy premises. If a problem of pathogenic bacteria in the products arises, it may be because persistent biofilms and bacteria associated with them, have formed in the milk pipes and cheese-making equipment. If this is the case, the biofilms must be removed by thorough cleaning and disinfection. It should also be mentioned that even lactic acid bacteria, such as lactobacilla, can form persistent biofilms, in which pathogens can develop, on cheese-making equipment ${ }^{66}$.

Biofilms can be described as a microbial community, in which bacterial cells adhere to solid substrates, to one another or to a surface. Fifteen percent of a biofilm is composed of micro-organisms. The remainder is composed of polysaccharides and glycoproteins. For more information on biofilms, see Appendix 9 "The effects of biofilms in small-scale cheese-making, Sven Lindgren, Biofood AB, Sweden”.

\section{Did you know that:}

Organisms that are attached to a biofilm have greater resistance to different types of biocides. S. aureus was shown to be eight times as resistant to chlorine when it occurred as part of a biofilm than when it occurred alone ${ }^{67}$.

\section{Hints for cheese-making}

Utensils and cheese-making equipment should be cleaned as soon as possible after cheese-making to avoid the risk of biofilms forming on surfaces. After cheese-making, cheese vats and other equipment used should be put to soak and should then be

\footnotetext{
${ }^{64}$ http://www.eldrimner.com//1685.rapporter_bocker.html och http://www.slv.se/sv/grupp2/Livsmedelsforetag/Branschriktlinjer1/Guide-till-god-hygienisk-praxis-vid-hantverksmassig-tillverkning-av-ost-och-andramjolkprodukter-och-vagledning-i-eget-HACCP-arbete---Eldrimner-Nationellt-resurscentrum-for-mathantverk/ 65 http://www.eldrimner.com//1685.rapporter_bocker.html och http://www.slv.se/sv/grupp2/Livsmedelsforetag/Branschriktlinjer1/Guide-till-god-hygienisk-praxis-vid-hantverksmassig-tillverkning-av-ost-och-andramjolkprodukter-och-vagledning-i-eget-HACCP-arbete---Eldrimner-Nationellt-resurscentrum-for-mathantverk/ ${ }^{66}$ Cheese, Chemistry, Physics and Microbiology, 3:ed, Fox, P,F., Mcsweeney, P.L.H., Cogan, T,M., Guinee, T.P., Elsevier 2004.

67 Bilaga 9: Inverkan av biofilmer vid småskalig osttillverkning, Sven Lindgren, 2009
} 
cleaned thoroughly once sensitive products have been removed from the cheese-making premises.

Cleaning and washing-up should not take place during the cheese-making process, as cheese may become contaminated by micro-organisms that can be transported via the tiny drops of water (aerosols) that are spread in the air during the cleaning and washingup process.

Hints from Swedish Dairy Association to milk producers ${ }^{68}$ regarding biofilms in milking equipment

High washing-up temperature: $60-70^{\circ} \mathrm{C}$

Sufficient washing-up time: 8-10 minutes

Correct dosage of washing-up detergent

Mechanical cleansing

Information about washing-up and cleaning can be found in Eldrimner's guidelines for cheese making "Prerequisite programme and working schedules" ${ }^{69}$. Disinfection can be carried out using alcohol (70\%), or by flaming with a gas burner or sterilising in boiling water. There are many different sorts of chemical disinfectants, in which the active agent can be composed of non-organic chloride compounds, peroxides or quaternary ammonium compounds. The advantage of the latter is that, in a diluted form, it can be used without extensive protective equipment. In summer-pasture villages, cheese moulds are often boiled, but sometimes they are soaked in water, or in water in which juniper branches have been soaked, or in whey ${ }^{70,71}$. The essential oils present in juniper berries, juniper needles and juniper wood seem to have a bacteria-inhibiting effect. However, it is difficult to say how much juniper berries/branches are needed to make a solution that will have the desired effect on pathogenic bacteria.

\section{Did you know that:}

In a study made in southern Serbia, essential oils from juniper berries (Juniperus communis) were examined to test their antimicrobial effect on bacteria such as $\mathrm{S}$. aureus and $\mathrm{E}$. coli. The results showed that the fractions containing -pinene and sabinene had the greatest antimicrobial activity ${ }^{72}$. In another study ${ }^{73}$, the antimicrobial activity of three different juniper oils was compared. The results showed that there was great variation between the three oils. This was probably due to the origin of the juniper berries and the locality in which they had grown. The antimicrobial effect of juniper berry oil is probably the synergetic effect of a number of components. Both juniper needles and wood also contain essential oils, but not to the same extent as the berries.

\footnotetext{
${ }^{68}$ Diska bättre för färre bakterier, Anders Christiansson, Djurhälso- \& Utfodringskonferens workshops, 27th August 2009, Uppsala

${ }^{69} \mathrm{http}: / /$ www.eldrimner.com//1685.rapporter_bocker.html och http://www.slv.se/sv/grupp2/Livsmedelsforetag/Branschriktlinjer1/Guide-till-god-hygienisk-praxis-vid-hantverksmassig-tillverkning-av-ost-och-andra-mjolkprodukter-och-vagledning-i-eget-HACCP-arbete---Eldrimner-Nationellt-resurscentrum-for-mathantverk/

${ }^{70}$ Bilaga 10: Användning och hantering av olika material vid osttillverkning på ett urval av svenska fäbodar. Lena Eriksson

${ }^{71}$ Bilaga 8: Forekomst og forebygging av uønska mikroorganismer og fremmedstoffer i smskala mjölkeforedling i Norge. Resurssentret, Sogn Jord og Hagebruksskule. Ragnhild Nordbo, Pascale Baudonnel, 2008

${ }^{72} \mathrm{Glisic}$, S.B. et al. Antimicrobial activity of the essential oil and different fractions of Juniperus communis L. and comparison with some commercial antibiotics. J. Serb. Chem. Soc. 72 (4) 311-320 (2007)

${ }^{73}$ Filipowicz, N, et al. Antibacterial and antifungal Activity of Juniper Berry Oil and its Selected Components. Phytother. Res 17, 227-231 (2003)
} 



\section{Cleaning wooden equipment}

In traditional cheese-making in summer-pasture villages, spruce is used for making cheese moulds, butter-making equipment and storage shelves for ripening cheeses. The wooden cheese moulds are usually washed-up in warm or hot water, with or without detergent. In some cases water in which juniper branches have been soaked is used for washing-up. Most of the cheese-makers in this type of traditional production say that it is important that the wooden equipment has a chance to dry between each cheese-making. Wooden shelves for ripening are usually scrubbed in clean water and are then sprayed with diluted acetic acid, as a precaution against Listeria bacteria ${ }^{74}$. For more information on the use of different equipment see Appendix 10: "The use and management of different materials in connection with cheese-making at various summer-pasture villages".

Hint

Acetic acid with a concentration of $0.1 \%$ seems to inhibit most pathogens and other bacteria that lead to the decomposition of food ${ }^{75}$. Acetic acid has the advantage that it is easy to use and is inexpensive in comparison with other substances such as solutions containing quaternary ammonium compounds.

Table for dilution of $0.1 \%$ acetic acid solution:

Acetic acid concentration Amount of acetic acid to 10 litres of water

$\begin{array}{rr}24 \% & 0.42 \mathrm{dl} \\ 12 \% & 0.82 \mathrm{dl} \\ 10 \% & 1 \mathrm{dl}\end{array}$

At the symposium "Safety Issues of Raw Milk Cheese" (which is summarised in Appendix 3), René Imhof stressed the importance of suitable premises and equipment for cheese-making. Listeria is principally a problem associated with surfaces, as studies have shown that L. Monocytogenes cannot survive the production process for semisoft, semi-hard or hard cheeses. Contamination takes place during the ripening process, through handling, equipment etc. His experience is that wooden shelves represent a risk factor, as neither mechanical nor chemical cleansing can guarantee that the shelves are sufficiently clean. Sterilisation in boiling water or heating in an autoclave are the most effective methods ${ }^{76}$.

\footnotetext{
${ }^{74}$ Bilaga 8: Forekomst og forebygging av uønska mikroorganismer og fremmedstoffer i smskala mjölkeforedling i Norge. Resurssentret, Sogn Jord og Hagebruksskule. Ragnhild Nordbo, Pascale Baudonnel, 2008

${ }^{75}$ Livsmedelsteknologi 1 Konserveringsmetoder, P.E Andersen, J Risum, Studentlitteratur 1991

${ }^{76}$ Bilaga 3: Sammanfattning av symposiet "safety Issues of Raw Milk Cheese" i Bryssel 2008-12-11-12,

Ann-Charlotte Steneryd. Falkenber Miljö och hälsa
} 
Making equipment out of slow-grown spruce with narrow annual growth rings minimises the equipment's water-absorbing ability, as the narrow annual growth rings are mainly composed of wood with a low water-absorbing ability.

\section{Did you know that:}

If analyses of products show that they contain pathogenic bacteria, these may comefrom biofilms containing pathogenic bacteria. Wooden equipment is difficult to clean, as pores in the wood impair the cleansing process. Research provides no evidence that wood, as such, has a sanitising effect on pathogenic bacteria ${ }^{77}$. One article $^{78}$ claims that components of essential oils from coniferous trees may have an inhibiting effect on bacteria such as L. Monocytogenes. The bacteria-inhibiting effect of these oils when they are bound in the wood is uncertain, as the concentration of oils is no doubt lower than when the oils are extracted.

\section{Cleaning and care of copper equipment}

Cheese-making in a copper pan initially has a de-activating effect on microorganisms, but this effect is reduced when a biofilm develops on the surface of the copper, which happens when it comes into contact with milk ${ }^{79}$. When the copper pan is washed-up it is important to make sure that the pan is thoroughly cleansed from any biofilm or copper-oxide, as this can be dissolved by the milk relatively easily and can contaminate the product with copper. To clean the pan thoroughly, an acid agent, such as citric acid, acetic acid or acid whey should be used in combination with a scouring agent such as fine sand or salt. This method is described in Eldrimner's guidelines for cheese-making "Prerequisite programme and working schedules" ${ }^{80}$. It is important that the copper pan is not dented, as this makes cleaning much more difficult. Studies have been made in France of whether cheese-making in copper pans can give rise to copper toxicity, but it was not found to be a problem. However, some of the cheeses made in Nordic countries are more acid than French cheeses, so the risk of copper leaching into the product is greater when making "mese" from whey, "gammelost", "pultost" and "surost/ surprim", as they have both a low $\mathrm{pH}$ and must be boiled for a long time. However, there is no record of copper toxicity in this type of cheese ${ }^{81}$.

\section{Did you know that:}

When making cheese in a copper pan, a higher dosage of starter culture is sometimes used to compensate for the fact that copper inhibits the activity of the lactic acid bacteria.

\footnotetext{
77 Bilaga 9: Inverkan av biofilmer vid småskalig osttillverkning, Sven Lindgren, 2009

${ }^{78}$ Mourey, A and Canillac, N,. Anti-Listeria monocytogenes activity of essential oils components of conifers. Food Control, Volume 13, Issues 4-5, June-July 2002 Pages 289-292

${ }^{79}$ Bilaga 9: Inverkan av biofilmer vid småskalig osttillverkning, Sven Lindgren

${ }^{80}$ http://www.eldrimner.com//1685.rapporter_bocker.html och http://www.slv.se/sv/grupp2/Livsmedelsforetag/Branschriktlinjer1/Guide-till-god-hygienisk-praxis-vid-hantverksmassig-tillverkning-av-ost-och-andramjolkprodukter-och-vagledning-i-eget-HACCP-arbete---Eldrimner-Nationellt-resurscentrum-for-mathantverk/ ${ }^{81}$ Bilaga 8: Forekomst og forebygging av uønska mikroorganismer og fremmedstoffer i småskala mjölkeforedling i Norge. Resurssentret, Sogn Jord og Hagebruksskule. Ragnhild Nordbo, Pascale Baudonnel, 2008
} 


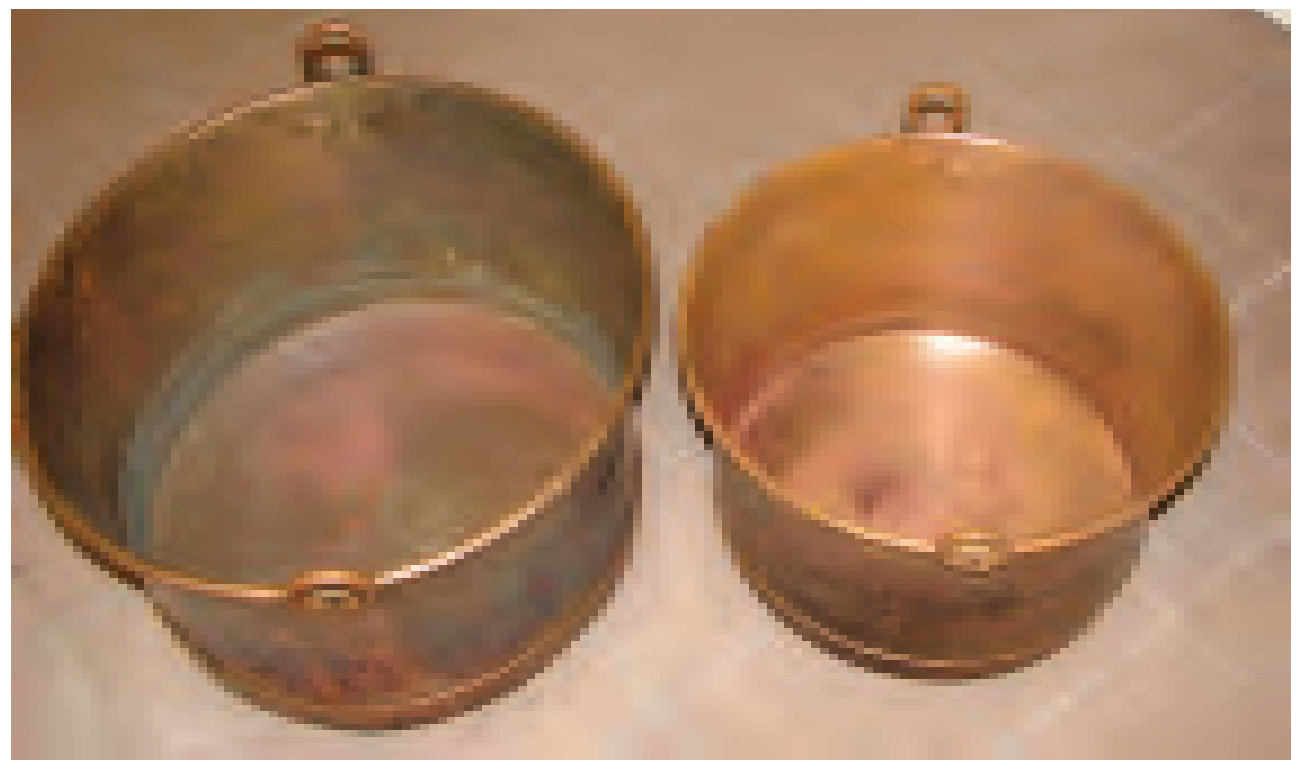

Illustration 7. Copper pans before and after cleaning

\section{The design and maintenance of dairy premises and equipment}

The production premises shall be designed in a way that avoids contamination from the flow through the working area of products, members of staff, air, and packaging. Unfortunately, a common problem is that there is often too little space for maturing and for packaging cheeses. One solution is to limit the range of cheeses produced or to carry out cheese-making and packaging at separate times, allowing time to clean the premises and for the surfaces to dry in between the different activities. For further information, see the relevant legislation in Norway, Sweden and Iceland.

Maintenance of the dairy comprises the physical maintenance of the premises, equipment and furnishings, including the surfaces and material such as pipes, washers and ventilation filters. The maintenance planning and schedules can be illustrated by an annual wheel chart (see Figure 1). The wheel chart can also specify times for major cleansing activities that are necessary from time to time, such as thorough cleaning of the premises, pasteurisation of brine etc.

The verification of measuring instruments for measuring critical control points is included in the HACCP plan. Schedules for the verification of other measuring equipment in the dairy are also necessary ${ }^{82}$, for instance, control and calibration of thermometers, calibration of $\mathrm{pH}$ meters and measuring instruments for checking the salt-content of brine.

82 Bilaga 6: Analysutrustning för gårdsmejerier, Ida Olofsson 


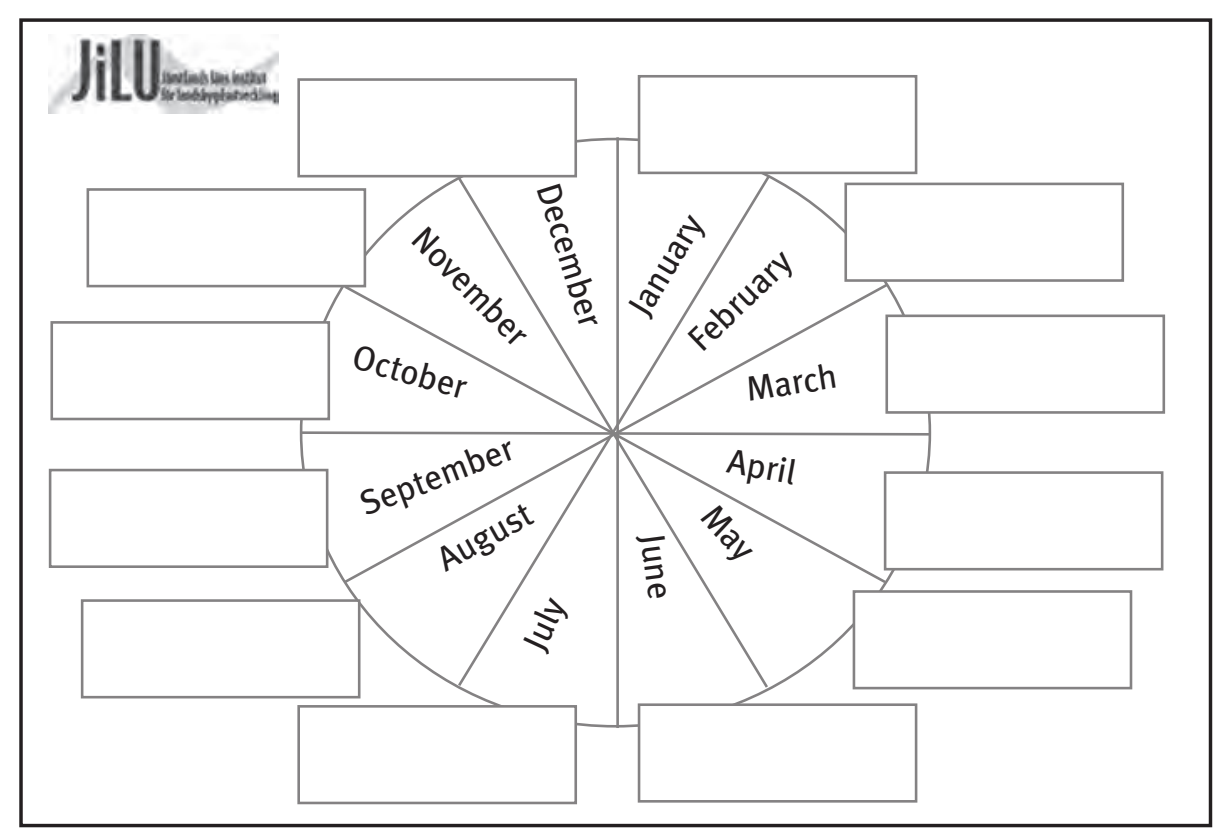

Figure 1. An example of an annual wheel chart from Rösta Educational Dairy

\section{Temperature, reception of milk and waste management}

For information on these factors, see the relevant legislation and guidelines in Norway, Sweden and Iceland. Some of these aspects, such as temperature and the reception of milk, are part of the prerequisite programme and are discussed under the headings "Critical control points for pasteurised cheese" and "Critical control points for unpasteurised cheese".

\section{Traceability}

In order to enable products to be traced in the chain of production, certain parts of the production and distribution process must be documented. More information can be found in "Guidance to compliance with EU Regulation 178/2002 on traceability" ${ }^{33}$ and in "Information to producers on traceability" ${ }^{44}$.

Traceability of the milk used in the dairy is necessary. If the milk is bought from another producer, any available analyses of the quality of the milk should be noted in the cheese-making record sheet or in another traceable system for documentation.

Traceability of the dairy's products will be achieved through the following documentation:

1. Which batch of cheese is delivered to which shop or restaurant

2. The date a given batch of cheese is first sold and when the last of the batch is sold, if the cheese is sold directly to customers.

\footnotetext{
83 http://ec.europa.eu/food/food/foodlaw/guidance/guidance_rev_8_en.pdf

${ }^{84}$ http://www.slv.se/upload/dokument/livsmedelsforetag/vagledningar/sparbarhet_information_till_livsmedelsforetagare.pdf
} 
Should the need to withdraw a product from the market arise, the producer will be well prepared if they always have a list of the relevant addresses and telephone numbers and the necessary documents for the withdrawal of a product should be prepared in advance. If a product must be withdrawn, the relevant parties should be contacted via telephone and written information should be sent to the relevant shops and restaurants and should be published in the local newspapers. The withdrawal of products should be reported to the relevant authorities.

\section{Fair practices - correct labelling that matches the recipes and routines used}

"Fair practices" means that the information provided on the cheese labels is correct, i.e. that there is a well-organised production process and that good production schedules are carefully adhered to. This is described in Eldrimner's guidelines "Guidestart" Fair practices can also mean that the company employs efficient labelling routines and that the information provided on the label is in accordance with the recipe used and the product description (see following page) of the product in question. It also implies that the company has routines for following-up products throughout the chain of production. Much of this is included in the prerequisite programme that should be part of the producer's system for own control.

It is extremely important that the consumer receives the correct product and that it is correctly labelled. This is especially important in the case of cheeses that are classified as hazardous for individuals with impaired immunity, for the elderly, or for children and pregnant women. The consumer should always be able to see if the cheese is made from pasteurised or unpasteurised milk. Pre-packaged products should always be clearly labelled. In the case of products that are not pre-packaged and that are sold directly to the consumer, it should be possible for the consumer to receive the same information verbally. There is also legislation on labelling, for instance in EC Regulations and in the National Food Administration's regulations on the labelling and presentation of foodstuffs and in their regulations on milk and cheese ${ }^{86}$. The Swedish National Food Administration also provides guidance to compliance with some of the legislation on its homepage, for instance to the regulations on the labelling and presentation of foodstuffs ${ }^{87}$. Internal and external interchange of information is an important part of how to prevent errors, and of how to limit the proportions of damage in the event of an error. Internal interchange of information can be done by word of mouth and or by written information between workers. The external interchange of information can be organized by preparing a guide indicating the preventive measures that ought to be taken in case of an error, and who to contact.

\footnotetext{
${ }^{85} \mathrm{http} / /$ www.eldrimner.com//1685.rapporter_bocker.html och http://www.slv.se/sv/grupp2/Livsmedelsforetag/Branschriktlinjer1/Guide-till-god-hygienisk-praxis-vid-hantverksmassig-tillverkning-av-ostoch-andra-mjolkprodukter-och-vagledning-i-eget-HACCP-arbete---Eldrimner-Nationellt-resurscentrum-formathantverk/

${ }^{86} \mathrm{http}: / /$ www.slv.se/sv/grupp2/Lagstiftning/Gallande-lagstiftning/Mjolk-och-ost/

$87 \mathrm{http}: / /$ www.slv.se/upload/dokument/livsmedelsforetag/vagledningar/vagledning_markning.pdf
} 
A product description must specify the factors and characteristics of a product/ process that can influence the HACCP plan (hazards), for instance the raw materials used, whether the milk is pasteurised or has been treated in any similar way, which consumers the product is suitable for etc.

A product description should provide a comprehensive description of the product that includes all relevant information such as:

- the group of consumers for which the product is suitable,

- contents,

- $\quad$ physical/chemical structure (including the water activity, $\mathrm{pH}$ etc),

- treatment that kills or inhibits the growth of micro-organisms (heat treatment, deep freezing, salting, smoking etc.),

- packaging material

- $\quad$ shelf-life and what this is based on,

- conditions for storage and

- $\quad$ method of distribution

In a company with a number of products, products with similar characteristics or processes can be grouped together when developing a HACCP plan ${ }^{88}$.

A recipe should include information on: the type of milk used, the temperature for cheese-making, dosage of starter culture, ingredients for flavouring (spices?), mould spores if used, instructions for pre-ripening, coagulation, cutting the curd, pre-stirring, scalding, further stirring, $\mathrm{pH}$ when draining, moulding, pressing, salting, surface treatment and maturing/ripening.

${ }^{88}$ http://www.codexalimentarius.net/download/standards/23/cxp_001e.pdf 


\section{Verification through testing samples}

A common misconception is that bad-tasting products necessarily indicate the presence of pathogenic bacteria. This may be true in certain cases, but in other cases it is not so. Tasting the products is an important part of quality control, but to be certain of the hygienic quality of the product, it must be combined with microbiological analyses. How many samples must be tested and what should be analysed? Testing samples is a complex issue. One problem is that it is difficult to take a representative sample of a solid foodstuff such as cheese, as the bacteria may be unevenly distributed in the product. The reliability of the tests is also greatly influenced by how large a percentage of the cheeses are contaminated and how many samples are analysed. The example below and information about testing samples is an excerpt from Appendix 4 "To test or not to test" 89 .

\section{Example}

When testing samples you should be aware that there is always a risk that you will not discover the bacteria you are testing for, even if they are present in some of the cheeses. How great is the probability of discovering an undesirable type of bacteria in a batch of cheese? The answer depends on what percentage of the cheeses are contaminated and how many samples are taken. The table below illustrates the probability of discovering a certain bacteria, such as L. monocytogenes, in relation to the number of tests.

The probability of discovering contaminated cheeses when testing samples:

\begin{tabular}{lccc} 
Number of samples analysed & \multicolumn{3}{c}{ Percentage of contaminated cheeses } \\
& $5 \%$ & $10 \%$ & $25 \%$ \\
\hline 1 & & & \\
5 & 0.05 & 0.10 & 0.25 \\
10 & 0.23 & 0.41 & 0.76 \\
& 0.40 & 0.65 & 0.94
\end{tabular}

\section{Explanation:}

- If a single sample is taken, the probability of discovering a cheese containing L. monocytogenes is not greater than the percentage of contaminated cheeses. For example, if one of ten cheeses is contaminated (10\%), bacteria will only be discovered in one of ten analyses (the probability is 0.10 ).

- If five samples are taken the probability of discovering a cheese containing L. monocytogenes increases, but the risk of not discovering contaminated cheeses is still great if the presence of the bacteria is low. If one of ten cheeses is contaminated (10\%), bacteria will be discovered in four of ten analyses (the probability is 0.41$)$.

\footnotetext{
${ }^{89}$ Bilaga 4: Prov eller inte prov- handledning för mikrobiologisk provtagning vid hantverksmässig tillverkning av ost. Åsa Rosengren, Mats Lindblad, Livsmedelsverket 2008
} 
- If ten samples are taken the probability of discovering a cheese containing L. monocytogenes increases further, but there is still a risk of not discovering contaminated cheeses. If one of ten cheeses is contaminated (10\%,) bacteria will be discovered in six-seven of ten analyses (the probability is 0.65 ).

It is difficult to demonstrate the presence of pathogenic bacteria during cheese-making by testing samples from cheeses that are ready for sale. One reason for this is that many bacteria die during the maturing / ripening process. Testing cheese should be carried out when the presence of the bacteria in question is likely to be at its highest. In the case of staphylococcus and E.coli bacteria, samples should be taken 6-24 hours after the start of the cheese-making process. In the case of L. monocytogenes it is often better to test environmental samples from different places in the dairy. Suitable places to test are surfaces that come into contact with the cheeses, such as shelves for maturation/ripening. Samples can be taken by rubbing the surfaces with a special environmental surface swab. Samples can also be taken from other places in the dairy, such as floor drains and the ventilation system.

Hint

\section{Planning of tests}

1. Contact the laboratory that is to make the analyses to check their prices and routines for how the results are reported (by telephone/email/post). Ask if they have any special instructions for submitting samples, e.g. the size/ number of samples, containers for samples, instructions for transport, labelling and times for submitting samples. Ask if it is possible to submit samples outside office hours (in an emergency) and what the cost would be.

2. Make a plan for how production should be monitored throughout the production year. The plan should include the type of cheese, type of bacteria and preliminary date for testing. This will make it possible to estimate the amount and cost of testing in advance. You must also be prepared to make extra analyses if the need should arise.

Certain cheeses are classified as hazardous with regard to L. monocytogenes. These include soft/semi-soft cheeses with a bloomy rind and soft/semi-soft cheeses with a washed rind. These cheeses have a high moisture content and a relatively high $\mathrm{pH}$, which means that Listeria bacteria can develop during the ripening process. Testing for Listeria bacteria in hazardous cheeses can be a relatively expensive process, but on the other hand these cheeses give a high cheese yield per litre milk in comparison with hard cheeses.

Appendix 4 comprises a report of the sub-project "To test or not to test" ${ }^{\text {" }}$. This contains recommendations for testing in different types of production and different types of cheeses. For further information, see EC Regulation no. 2073/2005 on microbiological criteria for foodstuffs ${ }^{91}$.

\footnotetext{
90 Bilaga 4: Prov eller inte prov- handledning för mikrobiologisk provtagning vid hantverksmässig tillverkning av ost. Åsa Rosengren, Mats Lindblad, Livsmedelsverket 2008

91 EC Regulation no. 2073/2005 on microbiological criteria for foodstuffs
} 
Testing products that are ready for sale is not a guarantee for food safety. Food safety can be achieved by following the measures that comprise good hygiene practice and by applying a system for monitoring the production process. Hygiene and monitoring routines should be verified regularly. One of the ways this can be carried out is by testing ${ }^{92}$.

Hint

By deep freezing samples of the milk and unsalted cheese from each cheese-making batch, an archive can be kept of all the cheese produced. However, an analysis of these samples may underestimate the amount of gram-negative rods, as these do not survive the deep-freezing temperature $\left(-20^{\circ} \mathrm{C}\right)$ as well as gram-positive bacteria $\mathrm{do}^{93}$. Furthermore, there is not any reliable evidence that measuring staphylococcus (gram-positive) bacteria gives exact results after freezing.

92 Bilaga 4: Prov eller inte prov- handledning för mikrobiologisk provtagning vid hantverksmässig tillverkning av ost. Åsa Rosengren, Mats Lindblad, Livsmedelsverket 2008

${ }_{93}$ Sánchez. A., Contreras. A., Jiménez. J., Luengo. C., Corrales. J.C., Fernández. C. Effect of Freezing goat milk samples on recovery of intramammary bacterial pathogens. Veterinary Microbiology 94 (2003) 71-77 



\section{Annex 1. \\ Current legislation on the current document}

\section{EC-regulations}

Regulation (EC) No 178/2002 laying down the general principles and requirements of food law, establishing the European Food Safety Authority and laying down procedures in mattering of food safety. [http://eur-lex.europa.eu/LexUriServ/LexUriServ.do?uri=CONSL EG:2002R0178:20090807:EN:PDF]

Regulation (EC) No 852/2004 on the hygiene of foodstuffs. [http://eur-lex.europa.eu/ LexUriServ/LexUriServ.do?uri=CONSLEG:2004R0852:20090420:EN:PDF]

Regulation (EC) No 853/2004 laying down specific hygiene rules for on the hygiene of foodstuffs. [http://eur-lex.europa.eu/LexUriServ/LexUriServ.do?uri=CONSLEG:2004R08 53:20100715:EN:PDF]

Regulation (EC) No 854/2004 laying down specific rules for the organization of official controls on products of animal origin intended for human consumption. [http://eur-lex. europa.eu/LexUriServ/LexUriServ.do?uri=CONSLEG:2004R0854:20100705:EN:PDF] Regulation (EC) No 882/2004 on official controls performed to ensure the verification of compliance with feed and food law, animal health and animal welfare rules. [http://eurlex.europa.eu/LexUriServ/LexUriServ.do?uri=CONSLEG:2004R0882:20090807:EN:PDF] Regulation (EC) No 2073/2005 on microbiological criteria for foodstuffs. [http://eur-lex. europa.eu/LexUriServ/LexUriServ.do?uri=CONSLEG:2005R2073:20100519:EN:PDF] Regulation (EC) No 2074/2005 laying down implementing measures for certain products under Regulation (EC) No 853/2004 of the European Parliament and of the Council and for the organization of official controls under Regulation (EC) No 854/2004 of the European Parliament and of the Council and Regulation (EC) No 882/2004 of the European Parliament and of the Council, derogating from Regulation (EC) No 852/2004 of the European Parliament and of the Council and amending Regulations (EC) No 853/2004 and (EC) No 854/2004, [http://eur-lex.europa.eu/LexUriServ/LexUriServ.do?uri=CONSLEG:2 005R2074:20090101:EN:PDF]

Regulation (EC) No 1234/2007 establishing a common organisation of agricultural markets and on specific provisions for certain agricultural products (Single CMO Regulation) [http://eur-lex.europa.eu/LexUriServ/LexUriServ.do?uri=CONSLEG:2007R1234:201101 01:EN:PDF]

Regulation (EC) No 1069/2009 of the European Parliament and of the Council laying down health rules as regards animal by-products and derived products not intended for human consumption and repealing Regulation (EC) No 1774/2002 (Animal by-products Regulation) [http://eur-lex.europa.eu/LexUriServ/LexUriServ.do?uri=CONSLEG:2009R10 69:20101109:EN:PDF]

Regulation (EC) No 142/2011 implementing Regulation (EC) No 1069/2009 of the European Parliament and of the Council laying down health rules as regards animal byproducts and derived products not intended for human consumption and implementing Council Directive $97 / 78 / \mathrm{EC}$ as regards certain samples and items exempt from veterinary checks at the border under that Directive Text with EEA relevance [http://eur-lex.europa. eu/LexUriServ/LexUriServ.do?uri=0]:L:2011:054:0001:0254:EN:PDF] 


\section{Guidance document}

Guidance document Implementation of procedures based on the HACCP principles, and facilitation of the implementation of the HACCP principles in certain food businesses [http://ec.europa.eu/food/food/biosafety/hygienelegislation/guidance_doc_haccp_ en.pdf]

Guidance document Implementation of certain provisions of Regulation (EC) No $852 / 2004$ on the hygiene of foodstuffs [http://www.slv.se/upload/dokument/livsmedelsforetag/vagledningar/guidance_doc_852-2004-new_en.pdf]

Guidance document Implementation of certain provisions of Regulation (EC) No 853/2004 on the hygiene of food of animal origin [http://www.slv.se/upload/dokument/livsmedelsforetag/vagledningar/guidance_doc_853-2004-new_en.pdf]

\section{Sweden}

Livsmedelslagen (SFS 2006:804)

Livsmedelsförordningen (SFS 2006:813)

\section{Livsmedelsverkets föreskrifter}

Livsmedelsverkets föreskrifter om livsmedelshygien (LIVSFS 2005:20)

Livsmedelsverkets föreskrifter om mjölk och ost (SLVFS 2003:39)

Livsmedelsverkets föreskrifter om offentlig kontroll av livsmedel (LIVSFS 2005:21)

Livsmedelsverkets föreskrifter om avgifter (LIVSFS 2005:23)

Livsmedelsverkets föreskrifter om material och produkter avsedda att komma i kontakt med livsmedel (SLVFS 2003:2)

Livsmedelsverkets föreskrifter om dricksvatten (SLVFS 2001:30)

Livsmedelsverkets föreskrifter om märkning och presentation av livsmedel (LIVSFS

2004:27)

\section{Livsmedelsverkets vägledningar}

Livsmedelsverkets vägledning till Livsmedelsverkets föreskrifter om dricksvatten Livsmedelsverkets vägledning om offentlig kontroll av livsmedel

Livsmedelsverkets vägledning om godkännande och registrering av livsmedelsanläggningar Livsmedelsverkets vägledning om hygien

Livsmedelsverkets vägledning till märkning

Livsmedelsverkets vägledning kontroll av värmebehandlingsutrustning för mjölk och mjölkprodukter

Livsmedelsverkets vägledning till offentlig kontroll vid mindre mjölkproduktföretag Livsmedelsverkets vägledning om livsmedelskontroll i primärproduktionen

\section{Branschriktlinjer och övriga dokument}

Branschriktlinjer från Svensk Mjölk och "Guide till god hygienisk praxis vid hantverksmässig tillverkning av ost och andra mjölkprodukter och vägledning i eget HACCP-arbete”, Eldrimner nationellt resurscentrum för mathantverk, 2009. Del 1: Guidestart, Del 2: Grundförutsättningar och arbetsrutiner, Del 3: Arbetsblad (14 st). 


\section{Norway}

Lov om matproduksjon og mattrygghet mv. (matloven). [http://www.mattilsynet.no/regelverl/lover/lov_om_matproduksjon_og_mattrygghet_mv__matloven_5536

EF forordning 2073/2005 Mikrobiologiske kriterier for næringsmidler . [http://www.mattilsynet.no/mattilsynet/multimedia/archive/00036/Forordning_-_norsk_-_36271a.pdf Forskrift om særlige regler for offentlig kontroll av produkter av animalsk opprinnelse beregnet på konsum (Forordning (EF) nr. 854/2004) H3.(Hr ej trädit i kraft ännu) [http://www. lovdata.no/cgi-wift/ldles?doc=/sf/sf/sf-20081222-1622.html]

Forskrift om særlige hygieneregler for næringsmidler av animalsk opprinnelse (Forordning (EF) nr. 853/2004) H2.(har ej trädit i kraft ännu) [http://www.lovdata.no/cgi-wift/ Idles?ttdoc=/for/ff-20081222-1624.html]

FOR 1995-06-30 nr 636 Forskrift om produksjon og omsetning mv. av råmelk, varmebehandlet melk og melkebaserteprodukter. [http://www.lovdata.no/cgi-wift/ldles?doc=/sf/ sf/sf-19950630-0636.html] Forskrift om næringsmiddelhygiene (Forordning (EF) nr.852/2004) H1. [http://www.lovdata.no/cgi-wift/ldles?doc=/sf/sf/sf-19971112-1239.html] FOR 1993-12-21 nr 1384: Forskrift om identifikasjonsmerking av næringsmiddelpartier. [http://www.lovdata.no/cgi-wift/ldles?doc=/sf/sf/sf-19931221-1384.html]

FOR-2001-12-04-1372: Forskrift om vannforsyning og drikkevann (Drikkevannsforskriften). [http://www.lovdata.no/cgi-wift/ldles?doc=/sf/sf/sf-20011204-1372.html] FOR 1993-12-21 nr 1381: Forskrift om materialer og gjenstander i kontakt med næringsmidler (Matkontaktforskriften). [http://www.lovdata.no/cgi-wift/ldles?doc=/sf/sf/sf19931221-1381.html]

FOR 1953-07-17 nr 9637: Forskrift om melk og fløte m.v. [http://www.lovdata.no/cgi-wift/ Idles?doc=/sf/sf/sf-19530717-9637.html]

FOR 1993-12-21 nr 1385: Forskrift om merking mv av næringsmidler. [http://www.lovdata. no/cgi-wift/ldles?doc=/sf/sf/sf-19931221-1385.html]

FOR 1956-08-24 nr 9632: Forskrifter om tilvirking, merking og omsetning av ost. [http:// www.lovdata.no/cgi-wift/ldles?doc=/sf/sf/sf-19560824-9632.html]

FOR 1962-11-16 nr 9581: Forskrifter om tilvirking, merking og omsetning av smør og smørfett. [http://www.lovdata.no/cgi-wift/ldles?doc=/sf/sf/sf-19621116-9581.html] Mattilsynets tilsynsveiledere for mindre matbedrifter, Melkeforedlingsvirksomheter. [http://www.mattilsynet.no/regelverk/veiledere/mat/tilsynsveileder_for_mindre_matbedrifter_19184]

FOR 2004-12-23 nr 1809: Forskrift om sporbarhet av næringsmidler og fôr [http://www.lovdata.no/cgi-wift/ldles?doc=/sf/sf/sf-20041223-1809.html] 


\section{Iceland}

Lov:

1995 nr. 93 28. júní “Lög um matvæli” (Almenn lov om matvareproduksjon)

[http://www.althingi.is/lagas/122a/1995093.html]

1988 nr. 81 3. ágúst “Lög um hollustuhætti og heilbrigðiseftirlit” (Lov om helse og tilsyn med matvareprodukstjon. Tar til hus, vann, kloak, söppel o.s. videre)

[http://www.althingi.is/lagas/122a/1988081.html]

919/2002 Regelværk:

“Reglugerð um mjólk og mjólkurvörur” (Detaljert regelværk angående melk og melkeprodukter)

[http://www.reglugerd.is/interpro/dkm/WebGuard.nsf/b7fd33650490f8cf00256a-

07003476bb/a2fcdd33dd31aeb900256c9f004749ed?OpenDocument]

586/1993 “Reglugerð um merkingu næringargildis matvæla” (Regelværk om mærking av næringsinnhold av matvarere)

[http://www.reglugerd.is/interpro/dkm/WebGuard.nsf/8f4a7d7ca32eedc100256500005

$1607 \mathrm{a} / \mathrm{d} 88815965 \mathrm{ff}]$ 
Annex 2-10

The title appears under the heading The "Nordost" Projekct on page 9. 
Nordic Council of Ministers

Ved Stranden 18

DK-1061 Copenhagen K

www.norden.org

\section{Guidelines for food safety control of artisan cheese- making}

These guidelines have been formulated as part of the project "Nordic cooperation between representatives of the sector and food safety inspectors in order to simplify the food safety control of artisan cheese-making", also known as "Nordost" (Northern Cheese). The project is financed by the Nordic Council of Ministers and was initiated by the Nordic work group for "Food administration and user/consumer information" (the NMF group). The content of the guidelines and the appendices do not necessarily reflect the opinions of the Nordic Council of Ministers or the National Food Administration.

Artisan cheese-making takes place under greatly varying conditions, which can include everything from cheese-making in tiled dairies to production in primitive summerpasture villages. Nevertheless, irrespective of the environment in which it takes place, the cheese-making process is the same and the same demands apply, namely that the cheese shall be safe for consumers to eat.

It is the producers duty to ensure that the cheese does not represent a health hazard, and that it is suitable for human consumption.

The objective of these guidelines is to provide support to food safety inspectors in carrying out efficient food safety control by focusing on the relevant hazards associated with artisan cheese-making, but also to disseminate the results of the sub-projects in "Nordost" to producers and other interested parties. Several of these sub-projects have studied relevant literature and tested equipment that enables simple effective own control by producers. 